\title{
RELIGIJNOŚĆ MATURZYSTÓW PUŁAWSKICH W PROCESIE PRZEMIAN
}

W opinii wielu polskich socjologów religijność społeczeństwa polskiego w okresie transformacji ustrojowej nie podlegała radykalnym przemianom, zarówno w zakresie praktyk religijnych, jak i subiektywnej religijności oraz religijnego i społecznego zaufania do Kościoła katolickiego. Jeszcze w 2008 roku - w opinii niektórych socjologów - katolicyzm młodzieży szkolnej i akademickiej, pomimo pewnej złożoności, przejawiał charakter stabilizacyjny ${ }^{1}$. Nieco inaczej oceniali Polacy zmiany w religijności w latach 1989-2014. Według sondażu CBOS z 2014 roku wśród dorosłych Polaków 2\% badanych wskazywało na zdecydowaną poprawę (wzrost) religijności w społeczeństwie polskim, 8\% - umiarkowaną poprawę (wzrost), 11\% - brak zmian (stabilizacja), 46\% - umiarkowane pogorszenie (spadek), 22\% zdecydowane pogorszenie (spadek) i 12\% - trudno powiedzieć ${ }^{2}$. To, że religia traci na znaczeniu w życiu codziennym Polaków, jest dość powszechnie odczuwane, jednak rzeczywiste przemiany w religijności nie muszą być tak dramatyczne, jak wynikałoby to z deklarowanych odczuć społecznych.

Oczekiwania, że w warunkach demokratyzacji społeczeństwa, kiedy religia i Kościół nie będą spełniać funkcji kompensacyjnych, nastąpi spadek religijności i znaczenia Kościoła jako autorytetu społecznego i moralnego, okazały się przedwczesne. W okresie przemian społeczno-kulturowych, gospodarczych i politycznych w naszym kraju, naznaczonych niepewnością, zagrożeniem bezpieczeństwa, niepewną wizją jutra, narastającymi podziałami społecznymi, Kościół katolicki ofiarował wspólnotę ponad podziałami, gwarancję najważniejszych wartości i integrację wokół nich (,kontynuacja w warunkach zmiany”). Dopiero w ostatnich latach zaznaczyły się bardziej widoczne przekształcenia, zwłaszcza w odniesieniu

\footnotetext{
* PROF. DR HAB. JANUSZ MARIAŃSKi - Wydział Nauk Społecznych Katolickiego Uniwersytetu Lubelskiego Jana Pawła II; januszm@kul.lublin.pl

${ }^{1}$ Sławomir H. Zaręba. W kierunku jakiej religijności? Studia nad katolicyzmem polskiej młodzieży. Zakład Wydawnictw Statystycznych. Warszawa 2008 s. 508.

${ }^{2}$ Rafał Boguszewski. Oceny zmian w różnych wymiarach życia społecznego i politycznego w Polsce po roku 1989. „Komunikat z badań CBOS” 2014 nr 62 s. 2.
} 
do środowisk młodzieżowych ${ }^{3}$. Religii nie można już zaliczyć do spraw subiektywnie ważnych dla części młodzieży polskiej, nie wpisuje się ona w jej „,́́wiat przeżywany".

Jeszcze w latach 2001-2002 - według ogólnopolskiego sondażu obejmującego młodzież będącą w wieku 15-24 lata - zdecydowana większość badanych deklarowała się jako katolicy $(95 \%)$ i jako wierzący ( $41 \%$ - jestem wierzący i postępuję według nauk Kościoła; 39\% - jestem wierzący na swój sposób; 15\% - wierzę w Boga, choć nie stosuję się do nauk Kościoła). Ponad połowa ankietowanej młodzieży uczęszczała w każdą niedzielę do kościoła (6\% - częściej niż raz w tygodniu i 47\% - raz w tygodniu). Młodzi Polacy wzrastali w społeczeństwie, w którym religia była obecna i widoczna. Krzysztof Koseła komentator tych badań nie wykluczał, że w przyszłości obniży się „temperatura religijnych deklaracji” i zaznaczy się wyraźny spadek uczestnictwa ludzi młodych w mszach, nabożeństwach i innych spotkaniach religijnych ${ }^{4}$.

Irena Borowik zwraca uwagę na następujące symptomy przemian religijności w środowiskach młodzieżowych:

a) Spadek uczestnictwa w niedzielnych nabożeństwach, zaniedbywanie spowiedzi i komunii św. (także wielkanocnej), spadek powołań kapłańskich i zakonnych;

b) Upodobnienie się modelu religijności młodych kobiet do młodych mężczyzn. Wskaźniki religijności młodych kobiet poniżej 30. roku życia spadały szybciej niż ich rówieśników płci męskiej, co może rzutować w przyszłości na procesy socjalizacji religijnej w rodzinie;

c) Młodzież częściej niż dorośli angażuje się w działalność w stowarzyszeniach ateistycznych, racjonalistycznych i humanistycznych, nieraz otwarcie protestuje przeciwko praktykom Kościoła katolickiego, utrudniającym definitywne odejście z niego;

d) Młodzież krytycznie odnosi się do Kościoła jako instytucji, krytykuje duchowieństwo, a także katechetów i katechetki, zarzuca im niechęć do dyskusji, podawanie gotowych rozwiązań, sztywność całego przekazu religijnego5.

Z badań biograficznych wśród młodzieży wynika, że „znaczna część młodzieży nie czuje się podmiotem poszukującym odpowiedzi na nurtujące pytania związane z religią, ale matrycą, na której powiela się ten sam wzór. Musi to pozostawać w sprzeczności ze znanymi z psychologii procesami rozwojowymi, odkrywaniem $<j a>$, indywidualizacją i indywiduacją, a okres transformacji samorealizacyjne dążenia

${ }^{3}$ Irena Borowik. Przemiany religijne w Polsce na tle transformacji w Europie ŚrodkowoWschodniej i globalizacji. W: Globalny i lokalny wymiar religii. Polska w kontekście europejskim. Red. Irena Borowik, Andrzej Górny, Wojciech Świątkiewicz. Zakład Wydawniczy NOMOS. Kraków 2016 s. $10-11$.

${ }^{4}$ Krzysztof Koseła. Religijność młodych Niemców i Polaków. W: Młodzi Polacy i młodzi Niemcy w nowej Europie. Red. Krzysztof Koseła, Bernardette Jonda. Wydawnictwo Instytutu Filozofii i Socjologii PAN. Warszawa 2005 s. 251-262 i 283.

${ }^{5}$ Irena Borowik. Przemiany religijne..., s. 11-12. 
uwydatnił”. Należy podkreślić, że trudno jest mówić o młodzieży „W ogóle”. W różnych środowiskach społecznych kształtują się w nieco odmienny sposób postawy, opinie, aspiracje i zainteresowania, kariery życiowe, wzory zachowań obyczajowych i moralnych oraz religijność. Inna jest młodzież ze środowisk wielkomiejskich, inna ze średnich i małych miast, jeszcze inna jest młodzież mieszkająca we wsiach podmiejskich i peryferyjnych?

W okresie transformacji ustrojowej po 1989 roku młodzież polska była rozmaicie etykietowana: niedopuszczone pokolenie, wyposażeni, niepotrzebni, upośledzeni, o przedłużonym dojrzewaniu społecznym, społeczni konformiści, sfrustrowani, bez określonych sympatii politycznych, skupieni na karierze, wybierający strategie przystosowawcze, uczestnicy subkultur, normalsi, nieudacznicy, o strategii przetrwania i pogodzenia się z losem, pokolenie bez pokoleniowej tożsamości, pozbawieni poczucia stabilności, pokolenie porzucone, zmiany, dryfujące, pragmatyczni, konsumpcyjnie i statusowo zorientowani, nastawieni na sukcesy, pieniądze i konsumpcję, mający określone cele, „,notliwi” minimaliści, afiliatywni marzyciele, ambitni hedoniści, aktywni poszukiwacze, profesjonaliści, leniwi fantaści, zdeterminowani, niedopieszczone pokolenie, pokolenie wolontariuszy, młodzi kreatywni, dzieci swojego czasu, ofiary transformacji, młodzież sceptyczna, nieobywatelska, bezideowa, zagubiona i niepewna, pokolenie facebooka, przyszłość i nadzieja narodu, pokolenie zdystansowanych wobec Kościoła, pokolenie pontyfikatu Jana Pawła II, pokolenie JP II, pokolenie lednickie, młodzież świadomie przeżywająca wiarę, młode pokolenie emigrujące z Kościoła, religijni ale mało moralni, chcący żyć normalnie na przyzwoitym poziomie, zadowoleni i pogodni, pokolenie X, młodzi dorośli, młodzi gniewni, pokolenie transformacji, „odpływające” politycznie pokolenie i obojętne na sprawy publiczne, wycofani z aktywności społecznej, pokolenie nadziei, otwarte na świat, uśpiona generacja, wyłączone pokolenie, pokolenie historycznej nadziei i codziennego ryzyka.

Wszystkie te metafory i inne tu nie przywołane określają sytuację, w jakiej znajdują się ludzie młodzi. Niezależnie od tego, jak będziemy określać pokolenie młodych Polaków, jest to pokolenie znajdujące się w fazie głębokich przemian społeczno-kulturowych, także przemian wartości i norm moralnych i religijnych. Wzory osobowe, wartości i normy, style życia rodziców nie zawsze odpowiadają wymogom czasu, zwłaszcza w osiąganiu sukcesów życiowych. Zaznacza się rozbieżność w podstawowych orientacjach życiowych i wartościach charakteryzujących pokolenie rodziców i młodzieży. W różnorodności trudno jest dostrzec inną ważną stronę wartości i norm moralnych - ich uniwersalność i kontynuację. Nie można jednak ustalać reguł moralnych rządzących stosunkami społecznymi bez uprzedniego poznania faktycznego funkcjonowania społeczeństwa.

${ }^{6}$ Tamże s. 12.

7 Jolanta Szymańczak. Pogodzeni z losem, czyli o młodzieży okresu przemian. W: Dawne i nowe problemy społeczne. Szkice do obrazu społeczeństwa polskiego u progu XXI stulecia. Red. Andrzej Kojder. Kancelaria Sejmu. Warszawa 2002 s. 110-130. 
We wszystkich środowiskach społecznych postawy i zachowania młodzieży podlegają ustawicznym zmianom, przyspieszonym w warunkach modernizacji społecznej. „Dynamika zmian, zachodzących w obrazie młodzieży, wyprzedza często nasze możliwości ich rejestracji. Wyniki badań dezaktualizują się niezwykle szybko - na ich podstawie możemy raczej mówić, jaka była młodzież, niż jaka jest" uległo zmianie w uznawanych przez młodzież wartościach religijnych i moralnych, a także w wartościach prospołecznych, godnościowych i prorodzinnych, a także w celach i dążeniach życiowych. Postawy i zachowania młodzieży ze środowisk wielkomiejskich, dużych i małych miast oraz ze środowisk wiejskich zmieniają się w różnym tempie, do pewnego stopnia paralelnie do zmian w całym społeczeństwie.

Badania socjologiczne, których wstępne wybrane wyniki omawiamy w niniejszym artykule, dotyczą maturzystów puławskich w 2016 roku$^{9}$. Maturzyści wchodzą w nową fazę życia, którą socjologowie nazywają wczesną dorosłością, zwaną też późną adolescencją, którą określa się dwudziestolatków i osoby tuż po trzydziestce, cieszące się pewną niezależnością. Nie zawarły one jeszcze małżeństwa, ani nie założyły rodziny, a więc w dalszym ciągu eksperymentują ze swoimi relacjami i stylami życia ${ }^{10}$. Mają oni przed sobą ważne decyzje życiowe: albo podjąć pracę zawodową, albo kontynuować naukę na studiach wyższych w uczelniach państwowych lub niepaństwowych. W ich świadomości religijnej i moralnej zaznaczają się daleko idące przemiany. Młodość jest ważną przestrzenią życiową kształtowania się różnych postaci i form religijności.

W warunkach radykalnych zmian społecznych pojawiają się różnego rodzaju kryzysy tożsamości osobowej: indywidualnej i społecznej (grupowej). W odniesieniu do kryzysu tożsamości indywidualnej wskazuje się na deficyt tożsamości wyrażający się w nieadekwatnej definicji siebie i w braku przywiązania do określonych wartości i celów. Deficyt tożsamości jest typowym zjawiskiem charakterystycznym dla młodzieży, która wchodzi w dorosłe życie. Z jednej strony kwestionuje ona swoją dotychczasową tożsamość (pożegnanie z dzieciństwem), z drugiej zaś kwestionuje zastany świat ludzi dorosłych. Niekiedy towarzyszy temu zjawisko anomii ${ }^{11}$. Konflikt tożsamości oznacza współistnienie wielości definicji własnego „ja”, wewnętrznie niespójnych, a nawet wzajemnie sprzecznych. „W odróżnieniu od osoby cierpiącej na deficyt tożsamości (którą charakteryzuje brak przywiązania

${ }^{8}$ Anna Przecławska. Współczesna młodzież polska - jaka jest? Próba poszukiwania odpowiedzi. W: W trosce o młodzież. Edukacja, praca, obywatelstwo. Red. Jan Niewęgłowski. Wydawnictwo Salezjańskie. Warszawa 2004 s. 25.

9 Badania socjologiczne zostały zrealizowane w ramach grantu badawczego przyznanego przez Wyższą Szkołę Nauk Społecznych z siedzibą w Lublinie.

10 Anthony Giddens [współpraca Philip W. Sutton]. Socjologia. Tł. Olga Sara, Alina Szulżycka, Paweł Tomanek. Wydawnictwo Naukowe PWN. Warszawa 2012 s. 301.

${ }^{11}$ Edmund Wnuk-Lipiński. Świat międzyepoki. Globalizacja, demokracja, państwo narodowe. Wydawnictwo ZNAK. Instytut Studiów Politycznych PAN. Kraków 2004 s. 227-228. 
do jakichkolwiek wartości czy celów życiowych), osoba doświadczająca konfliktu tożsamości odznacza się silnym przywiązaniem do pewnych wartości lub celów życiowych, jednakże niektóre z tych wartości bądź celów nie dadzą się pogodzić, bo wymagają zaangażowania niespójnego z innymi celami, równie ważnymi dla jednostki. W tym przypadku wybór ważnego celu działania oznacza porzucenie innego, równie ważnego celu"'12.

W kontekście tej ogólnej tezy można założyć, że młodzież maturalna szczególnie przeżywa kryzys tożsamości, w tym także kryzys tożsamości religijnej i moralnej. Wartości religijne i moralne stają się kwestią wyboru i wykazują się brakiem stabilizacji w czasie i swoistą ambiwalencją. Jest to „cena”, jaką płacą jednostki w warunkach radykalnych zmian społecznych. Nowoczesne społeczeństwa zindywidualizowane i spluralizowane charakteryzują się różnorodnością celów życiowych, akceptowanych norm, światopoglądów i stylów życia. Brakuje konsensu w odniesieniu do wspólnie uznawanych wartości i ich hierarchii. Według Ireny Borowik orientacje religijne młodzieży polskiej zmieniają się powoli, nie jest widoczny jakiś wyrazisty i jednokierunkowy trend, ale pewne elementy zmian układają się w określone tendencje. W tym kontekście wymienia ona zmiany w obyczajowości przedmałżeńskiej, spadek regularnego uczestnictwa we mszy św., przesunięcie od deklarowanej wiary do niezdecydowania, obojętności religijnej, a nawet niewiary, krytyczny stosunek do katechezy szkolnej ${ }^{13}$.

Socjolog może śledzić zmiany w kondycji społecznej, moralnej i religijnej w następujących po sobie pokoleniach młodzieży polskiej. Powolne następowanie po sobie jednej generacji młodzieży przez następną w odniesieniu do kondycji religijnej i moralnej, może prowadzić do znaczących zmian w całym społeczeństwie. Oznaczałoby to zachwianie, a nawet - być może - przerwanie przekazu wartości i norm religijnych oraz moralnych motywowanych religijnie w rodzinie ${ }^{14}$. Obraz młodzieży polskiej jest zmienny i zróżnicowany, zarówno dzisiaj jak i w minionych kilkunastu latach. Zwłaszcza to drugie ujęcie wydaje się niezwykle ważne, zarówno z teoretycznego jak i praktycznego punktu widzenia. Młodzież współczesna zmienia się w dynamiczny sposób i to w krótkich odstępach czasu, w rozmaity sposób w różnych środowiskach społecznych.

Dla uchwycenia przemian w religijności i moralności młodzieży maturalnej zostały przeprowadzone w Puławach, mieście liczącym w 2014 roku 48,9 tys.

12 Tamże s. 228 .

13 Irena Borowik. Religijność w Polsce okresu transformacji - na tropach zmian. W: Polska początku XXI wieku: przemiany kulturowe i cywilizacyjne. Red. Krzysztof Frysztacki, Piotr Sztompka. Komitet Socjologii PAN. Warszawa 2012 s. 339-342. Jan Szymczyk. Przemiany wartości Polaków. Wybrane aspekty i tendencje. W: Społeczne i etyczne aspekty rozwoju społecznego. Red. Witold Jedynak, Jarosław Kinal. Wydawnictwo Uniwersytetu Rzeszowskiego. Rzeszów 2015 s. 17-22.

${ }^{14}$ Hans-Georg Ziebertz. Gibt es einen Tradierungsbruch? Befunde zur Religiosität der jungen Generation. W: Bertelsmann Stiftung. Religionsmonitor 2008. Gütersloher Verlagshaus. Gütersloh 2008 s. 44-53. 
mieszkańców (w 2002 roku - 50,6 tys.) ${ }^{15}$, trzykrotne badania ankietowe (1994, 2008/2009 i 2016). Warto nie tylko diagnozować postawy i zachowania młodzieży maturalnej, ale także postawić pytanie, co w okresie 22 lat zmieniło się i w jakim kierunku dokonują się zmiany w religijności i moralności młodzieży? Czy zmiany w religijności i moralności mają tylko charakter ilościowy, czy też i jakościowy, co jest inne, a co jest elementem kontynuacji?

Wnioski z jednego pomiaru zjawisk moralnych nie mogłyby określić zmian w religijności i moralności, tym bardziej upoważniać do wniosku o malejącym czy wzrastającym wpływie zasad moralnych na postępowanie ludzi, o malejącym czy wzrastającym wpływie religii na życie indywidualne i społeczne. Badanie takie będące swoistą fotografią hic et nunc mogłoby mieć charakter wyłącznie eksploracyjny, z kolei badania powtarzane pozwalają ustalić to, co zmieniło się w orientacjach religijnych i moralnych maturzystów w latach 1994/2016. Procesy zmian religijnych i moralnych były rejestrowane w trzech przekrojach czasowych (badania powtarzane) ${ }^{16}$. Ankietę audytoryjną przeprowadzono $\mathrm{w}$ czterech tych samych szkołach ponadgimnazjalnych w Puławach i w tych samych klasach (w I Liceum Ogólnokształcącym im. księcia Adama Czartoryskiego, w Społecznym Liceum Ogólnokształcącym im. Christiana Piotra Aignera, w Technikum nr 1 i w Technikum nr 2). Do dalszych analiz statystyczno-korelacyjnych w 2016 roku włączono 286 ankiet, co stanowiło 83,6\% założonej próby badawczej ${ }^{17}$. Narzędziem badawczym był kwestionariusz ankiety, pt. „Maturzyści a wartości moralne”, opracowany w 1993 roku w Katedrze Socjologii Moralności KUL, ubogacony w 2009 roku o kilka dodatkowych pytań.

W czterech szkołach ponadgimnazjalnych kilkanaście osób nie wypełniło ankiety, lub wypełniło ją tylko częściowo, inni byli - mimo ponawianych prób dotarcia do nich - nieosiągalni (w sumie 16,4\%). Deklarowane przez respondentów wartości religijno-moralne i wzory zachowań niekoniecznie są czymś zinternalizowanym. Respondenci udzielają niekiedy odpowiedzi, o których sądzą, że są one oczekiwane przez badacza lub ich samych stawiają w korzystnym świetle. Być może ma rację jedna z respondentek, gdy pisze: „Wydaje mi się, że człowiek w wieku licealnym ma jeszcze nie do końca ukształtowane poglądy na sporne tematy. Mimo dużego wpływu otoczenia nie jesteśmy w pełni świadomi wielu kwestii i oczywiście nie doświadczyliśmy w życiu tyle ile osoba dorosła. Brakuje nam styczności z niektórymi rodzajami problemów, np. natury politycznej. Mam też wrażenie, że ludzie często nie zastanawiają się nad problemami poruszonymi w ankiecie". Wydaje

${ }^{15}$ Rocznik Statystyczny Rzeczypospolitej Polskiej. GUS. Warszawa 2015 s. 214.

${ }^{16}$ Grzegorz Lissowski. Metody ilościowe. W: Encyklopedia socjologii. T. 2. Red. Władysław Kwaśniewicz. Oficyna Naukowa. Warszawa 1999 s. 222.

${ }^{17}$ Beata Maj-Gadomska. Wartości moralne w świadomości maturzystów (na podstawie badań socjologicznych w Puławach). Lublin 1995 (mps pracy magisterskiej). Dorota Nastalska. Wartości moralne w świadomości maturzystów. Na przykładzie wybranych szkół Puław. Lublin 2010 (mps pracy magisterskiej). 
się jednak, że zebrany materiał empiryczny w przybliżony sposób odzwierciedla rzeczywiste poglądy, opinie i postawy badanych maturzystów.

Stosunek młodzieży do ankiety był zróżnicowany: od ocen bardzo pozytywnych do ocen bardzo negatywnych, od głębokiego zainteresowania aż po znużenie i zniecierpliwienie. Respondenci zapytani wprost o opinię na temat ankiety udzielili odpowiedzi, które zostały sklasyfikowane według następujących kategorii: pozytywne, negatywne (zawierające krytykę lub propozycje zmian), pozytywno-negatywne i nieokreślone (ogólnikowe, nieprecyzyjne, nie na temat, wypowiedzi wulgarne). W całej zbiorowości młodzieży maturalnej 7,0\% badanych udzieliło odpowiedzi pozytywnych o ankiecie lub nie mieli uwag krytycznych, $22,4 \%$ - negatywnych, $2,1 \%$ - pozytywno-negatywnych, 5,6\% - nieokreślonych i $62,9 \%$ - zrezygnowało z prawa do zaopiniowania ankiety. Wypowiadane uwagi o ankiecie miały najczęściej formę krótkich zdań, tylko niekiedy wypowiadano się w szerszy sposób. Krytyka czy aprobata kwestionariusza ankiety dotyczyła albo jakichś konkretnych spraw (np. poszczególnych pytań), albo miała charakter bardziej ogólny (np. wątpliwości co do sensowności badań socjologicznych). Najczęściej zwracano uwagę na zbytnią obszerność ankiety oraz częste nawiązywanie do religii lub Kościoła.

W niniejszym artykule omówimy tylko kilka wybranych kwestii związanych z religijnością maturzystów puławskich: przynależność wyznaniowa, przynależność religijna, katolicyzm i polskość, autodeklaracje praktyk religijnych. W głównej hipotezie badawczej zakładamy, że młodzież maturalna znajduje się już w fazie zaawansowanej młodości, częściowo uniezależnia się już od rodziny pochodzenia, jej główne zainteresowania i działania przenoszą się poza rodzinę. Rozpoznaje ona już dokładnie swoje perspektywy życiowe, a równocześnie coraz wyraźniej ustala swoją hierarchię wartości i autonomię moralną. Następuje także zachwianie, a niekiedy i rozpad ukształtowanych w rodzinie wartości i norm, które w coraz mniejszym stopniu wpływają na postępowanie jednostek.

\section{PRZYNALEŻNOŚĆ WYZNANIOWA MATURZYSTÓW PUŁAWSKICH}

W warunkach transformacji ustrojowej nie dokonał się w społeczeństwie polskim gwałtowny rozpad dotychczasowych struktur religijno-kościelnych, powstają jednak nowe zróżnicowania religijne. Pełna diagnoza stanu religijności jest $\mathrm{w}$ chwili obecnej raczej wątpliwa, nie ma charakteru udokumentowanej ekspertyzy. Jedno jest pewne: w zmienionej sytuacji społeczno-kulturowej, coraz bardziej „,nieprzejrzystej”, wiele dotychczasowych poglądów dotyczących religii i Kościoła katolickiego w społeczeństwie polskim, zwłaszcza w środowiskach młodzieżowych, wymaga ponownego przemyślenia i sformułowania. Socjologowie zachodni odchodzą od zamiarów przepowiadania końca religii i początków ery całkowicie świeckiej. 
Mówi się nie tylko o procesach sekularyzacjyjnych, ale i o powolnym otwieraniu się ludzi współczesnych na religię i o przebudzeniu religijnym, nie tyle o zanikaniu sacrum, lecz o jego przemieszczaniu się w różnych sferach ludzkiego życia. Jeżeli nawet wskazuje się na erozję zorganizowanej religii (Kościoły chrześcijańskie nie są blokami monolitycznymi) i na niekoherentny system wierzeń w świadomości ludzi wierzących, to zwolennicy teorii sekularyzacji na ogół nie postulują już zaniku religii, ani całkowitego pożegnania człowieka z Bogiem.

Według tezy sekularyzacyjnej zmniejsza się z pokolenia na pokolenie witalność religijna, wzrasta dystans wobec Kościoła. Dystans wobec Kościołów chrześcijańskich jest przygotowaniem dystansu wobec religii ${ }^{18}$. Socjologia religii w Polsce natomiast stoi przed pokusą akceptacji skrajnej wersji tezy sekularyzacyjnej, nawiązującej do dokonujących się obecnie gwałtownych przekształceń w roli i pozycji Kościoła w społeczeństwie. Łatwo w tych warunkach o pokusę przepowiadania przyspieszonej sekularyzacji oraz bezwzględnego automatyzmu i determinizmu w przemianach religijności. Według tego scenariusza rozwoju wraz z postępem modernizacji społecznej musi dochodzić do sekularyzacji społeczeństwa, a proces ten jest $\mathrm{w}$ istocie nieunikniony i nieodwracalny. Zmiany w religijności nie przebiegają niezależnie od zmian w społeczeństwie, a procesy racjonalizacji, funkcjonalnej dyferencjacji, demokratyzacji, urbanizacji, migracji, wzrostu dobrobytu ludności wpływają niekorzystnie na społeczne znaczenie religii w społeczeństwie. Część polskich socjologów uznaje sekularyzację za integralną część procesów modernizacji społecznej.

W Polsce strukturę wyznaniową społeczeństwa można określać, na podstawie autodeklaracji badanych osób w trakcie sondaży opinii publicznej. Autodeklaracje wyznaniowe (przynależność wyznaniowa) odnoszą się do tzw. całościowych (globalnych) wyznań wiary i należą do najbardziej trwałych składników religijności. Nie zmieniają się one równolegle $\mathrm{z}$ dokonującymi się przemianami w makrostrukturze społecznej. Badani Polacy przyznają się w akcie autoidentyfikacji do poszczególnych wyznań religijnych, co w ich świadomości wiąże się z pewnymi przeżyciami, przekonaniami i gotowością do działania (ogólna religijność). W Polsce przynależność formalna do Kościoła katolickiego jest swoistą oczywistością kulturową.

Według sondażu CBOS z grudnia 2016 roku 91,7\% badanych dorosłych Polaków deklarowało przynależność do katolicyzmu; $0,8 \%$ - protestantyzm (wyznanie ewangelickie, ewangelicko-augsburskie); 0,7\% - prawosławie; 0,2\%-Chrześcijański Zbór Świadków Jehowy; 1,5\% - chrześcijaństwo ogólnie; 3,7\% - nie należę do żadnego wyznania, jestem agnostykiem, ateistą; 0,3\% - inne wyznanie; $1,2 \%$ - odmowa odpowiedzi. W styczniu 2017 roku wskaźnik deklarujących przynależność do katolicyzmu był jeszcze wyższy i wynosił 92,8\% (informacje uzyskane

${ }^{18}$ Gert Pickel. Religionssoziologie. Eine Einführung in die zentrale Themenbereiche. VS Verlag für Sozialwissenschaften. Springer Fachmedien. Wiesbaden 2011 s. 395. Krzysztof Koseła. Zmiany religijności młodzieży zarejestrowane w danych w Centrum Badania Opinii Społecznej. W: Dzieci swojego czasu. Młodzież polska i francuska. Ośrodek Badań Młodzieży Uniwersytetu Warszawskiego. Red. Joanna Kośmider, Anna Tyszkiewicz. Warszawa 1993 s. 92-97. 
w CBOS). W trzech badaniach ogólnopolskich zrealizowanych w latach 1988-2005 przez Instytut Statystyki Kościoła Katolickiego SAC przynależność do Kościoła katolickiego deklarowało około 90\% ogółu badanych uczniów i studentów. Pozostali to $\mathrm{w}$ połowie przedstawiciele innych wyznań oraz bezwyznaniowi ${ }^{19}$.

W zbiorowości młodzieży maturalnej z Puław w 1994 roku 83,9\% badanych deklarowało przynależność do Kościoła katolickiego, w 2009 roku - 90,0\%, w 2016 roku - 82,2\% (15,0\% - nieprzyznający się do katolicyzmu i 2,8\% - nieudzielający odpowiedzi). W latach 1994-2016 mieliśmy do czynienia z pewnym ewoluowaniem przynależności wyznaniowej, obecnie wskaźnik tej przynależności przesunął się wyraźnie poniżej granicy $90 \%$, ale mieści się jeszcze w granicach tzw. oczywistości kulturowej (powyżej 80\%). Procesy dekonfesjonalizacji w środowiskach młodzieżowych są jeszcze in statu nascendi ale są już wyraźniejsze niż w środowiskach ludzi dorosłych. Maturzyści bez przynależności wyznaniowej, nie deklarujący jakiegokolwiek związku z organizacjami i wspólnotami religijnymi (Kościołami), stanowią niewielką zbiorowość, o wyraźnych tendencjach wzrostowych. Prawdopodobnie w najbliższych latach ulegnie wzmocnieniu proces kształtowania się środowisk wyznaniowo niezorganizowanych, stojących „na uboczu”, nieokreślonych wyznaniowo, inaczej wierzących, określających siebie „raczej jako katolik”.

W 2016 roku wśród kobiet wskaźnik przyznających się do katolicyzmu był wyraźnie wyższy niż wśród mężczyzn $(88,7 \%$ wobec $72,9 \%)$, znacznie niższy wśród młodzieży z liceów ogólnokształcących niż z techników $(76,1 \%$ wobec $87,8 \%$ ), wyższy wśród młodzieży mieszkającej na wsi i w małych miastach niż w miastach powyżej 20 tys. mieszkańców, tj. w Puławach (90,4\% wobec 68,8\%). Uznający się za katolików znacznie częściej niż nieuznający się za katolików deklarowali się jako głęboko wierzący lub wierzący $(72,8 \%$ wobec $8,4 \%)$, częściej deklarowali, że religia jest bardzo ważna lub ważna w ich życiu $(79,6 \%$ wobec 8,4\%), częściej zgadzali się ze stwierdzeniem, że życie ma sens tylko dlatego, że istnieje Bóg $(59,2 \%$ wobec $25,0 \%)$, częściej deklarowali, że praktykują w każdą niedzielę i czasami w dni powszednie lub w każdą niedzielę $(28,1 \%$ wobec $8,4 \%)$. Jeżeli założymy, że zdecydowana większość spośród osób deklarujących brak przynależności do katolicyzmu (niewielka część spośród nich należy do innych wyznań chrześcijańskich lub religii pozachrześcijańskich) uprzednio należała do Kościoła katolickiego, to uzasadnionym wydaje się wniosek, że odejście od katolicyzmu było związane z utratą wiary i absencją w praktykach religijnych.

Wysoki poziom przynależności wyznaniowej konstatowano w innych środowiskach młodzieżowych na Lubelszczyźnie. Wśród maturzystów lubelskich w roku szkolnym 2009/2010 zdecydowana większość ankietowanych identyfikowała się z Kościołem rzymskokatolickim (92,6\%), 5,9\% - nie uważało siebie za katolików (członkowie innych wyznań religijnych, bezwyznaniowi), $0,2 \%$ - to niezdecydowani

${ }^{19}$ Sławomir H. Zaręba. Identyfikacje religijne i dylematy moralne uczniów i studentów w Polsce. „Collectanea Theologica” 79: 2009 nr 2 s. 167. 
i 1,3\% - nieudzielający odpowiedzi. Wskaźnik maturzystów przyznających się do katolicyzmu był wyższy wśród kobiet $(96,5 \%)$ niż mężczyzn $(88,2 \%)$; wyższy wśród maturzystów z liceów ogólnokształcących i techników (po 93,3\%) niż z liceów profilowanych (87,7\%); wyższy wśród młodzieży mieszkającej na wsi $(95,0 \%)$ niż mieszkającej w miastach do 100 tys. mieszkańców $(89,9 \%)$ i w miastach powyżej 100 tys. mieszkańców $(91,7 \%)^{20}$.

Wśród maturzystów z woj. lubelskiego w 2010 roku 92,2 \% badanych określiło swoje wyznanie religijne jako katolickie, $0,2 \%$ - prawosławne, $0,1 \%$ - protestanckie, $0,2 \%$ - zielonoświątkowe, $0,6 \%$ - pozachrześcijańskie, 4,2 \% - nienależący do żadnego wyznania, 2,6 \% - brak danych. Wśród rodziców lub opiekunów ankietowanych maturzystów przeważało również wyznanie katolickie (matki - 93,5\%, ojcowie - 89,8 \% $)^{21}$. Młodzież licealna z Puław w 2012 roku w 85,3\% określiła siebie jako katolików, w 9,9 \% - nieokreśliła siebie w ten sposób (niekatolicy) i 4,7\% - nie udzieliła odpowiedzi ${ }^{22}$. Wśród lubelskich studentów wolontariuszy zdecydowana większość przyznawała się do katolicyzmu $(98,4 \%)$ i deklarowała się jako wierząca $(96,0 \%)$ oraz praktykująca regularnie $(83,6 \%)^{23}$. Maturzyści puławscy rzadziej identyfikują się z Kościołem katolickim niż maturzyści Lubelszczyzny.

Faktem jest, że bycie katolikiem i do pewnego stopnia także katolikiem praktykującym jest swoistą normą kulturową, czymś jakby naturalnym i oczywistym. Niezależnie od tego, ile znaczy dla kogoś religia, należy być członkiem jakiegoś Kościoła. Bezwyznaniowość nie jest w modzie, a publiczne deklarowanie braku przynależności do jakiejś wspólnoty wyznaniowej, jeżeli nawet nie jest piętnowane społecznie, to bynajmniej nie jest aprobowane („Trudno powiedzieć, czy jestem katolikiem, czy nie jestem”; „Nie mam wyrobionych przekonan”; „Jestem pozornym katolikiem”; „Pośrodku między katolikiem i niekatolikiem”; „Nie wiem, kim jestem”; „Trochę na niby”; „Katolik pogański”; „Katolik niewierzący”; „Katolik ateistyczny").

Istotną zmianą w odniesieniu do przynależności wyznaniowej w Polsce jest to, że powoli zmienia się ona od przynależności kulturowo dziedziczonej, przyjmowanej jako coś oczywistego i określonego tradycją, do przynależności będącej konsekwencją świadomego i wolnego wyboru. Nie przeczy to innej tendencji, według której część Polaków, zwłaszcza młodych, nie do końca uświadamia sobie, co rzeczywiście oznacza wyrażenie „być katolikiem”. Znajdują się oni zresztą w niestabilnym i trochę ulotnym stadium swojego rozwoju religijnego. Polacy -

${ }^{20}$ Marcin Rola. Wartości moralne w świadomości maturzystów lubelskich. Studium socjologiczne. Wydawca i druk Drukarnia Standruk. Lublin 2016 s. 123-125.

${ }^{21}$ Ewa Miszczak. Świętość w religijnej świadomości maturzystów województwa lubelskiego. Studium socjologiczne. Wydawnictwo UMCS. Lublin 2014 s. 83.

${ }^{22}$ Ewa Panecka. Środowiskowe uwarunkowania zachowań altruistycznych młodzieży licealnej. Lublin 2015 (mps pracy doktorskiej) s. 253.

${ }^{23}$ Anna Kanios. Społeczne kompetencje studentów do pracy w wolontariacie. Wydawnictwo Uniwersytetu Marii Curie-Skłodowskiej. Lublin 2010 s. 93. 
także polska młodzież - niechętnie przyznają się do „bezdomności” wyznaniowej, nawet jeżeli ich więzi z określonym wyznaniem czy religią są bardzo osłabione, niemal żadne, a katolickość bardzo niejasna i nieokreślona. Tożsamość religijna w Polsce wiąże się w dalszym ciągu najczęściej z przynależnością wyznaniową do Kościoła katolickiego, dzieci najczęściej „,dziedziczą” przynależność wyznaniową po rodzicach. . Przezwyciężenie katolickiego monopolu na religijność dokonuje się W społeczeństwie polskim bardzo powoli.

Według ogólnopolskiego badania ludności Polski będącej w wieku 16 lat i więcej w 2015 roku 92,8\% ankietowanych odpowiedziało, że identyfikuje się z Kościołem katolickim (obrządek łaciński), 1,4\% - należało do innych wyznań religijnych, 3,1\% - nienależący do żadnego wyznania, 0,5\% - niepotrafiący określić swojej przynależności wyznaniowej i $2,2 \%$ - to odmawiający udzielenia odpowiedzi ${ }^{24}$. W porównaniu z ogółem ludności naszego kraju maturzyści puławscy przejawiają wyraźnie niższą przynależność do Kościoła katolickiego (różnica około 10\%). Różnią się w podobnym stopniu od młodzieży szkolnej z innych środowisk Lubelszczyzny. Zwyżkowy trend w zakresie przynależności wyznaniowej młodzieży puławskiej w latach 1994-2009 został zahamowany, a nawet nastąpił spadek poniżej stanu z 1994 roku. Maturzyści puławscy wciąż jednak tworzą środowisko, w którym element religijny jest czymś odczuwanym przez większość. Dla części maturzystów - trudnej do określenia - bycie katolikiem jest bardziej faktem kulturowym i tradycją niż kwestią wiary i osobistych przekonańn ${ }^{25}$.

W społeczeństwie polskim przynależność wyznaniowa (katolicka) łączyła się w przeszłości z polskością, a katolicyzm był traktowany jako niezbywalny element polskiej tożsamości narodowej i kultury. Można przypuszczać, że również z pojęciem „katolicyzm” i „katolik” kojarzą się różnorodne treści. Dla części respondentów będą to przede wszystkim elementy doktrynalne, dla części - elementy etyczne, jeszcze dla innych - elementy instytucjonalne czy kultowe. Niezależnie od treści zawierających się w pojęciach „katolik” i „Polak” mówi się dość często o postępującym kryzysie stereotypu „Polak - katolik” oraz idei katolickiego narodu polskiego. Badania socjologiczne wskazują na to, że rozluźnia się nieco syndrom modelu „Polak - katolik”.

W dokumencie Konferencji Episkopatu Polski pt. „Chrześcijański kształt patriotyzmu” podkreśla się, że swój wkład do życia i rozwoju naszej ojczyzny wnieśli wszyscy polscy obywatele, chociaż historia i tożsamość naszej ojczyzny szczególnie ściśle związała się z łacińską tradycją Kościoła katolickiego. „Dlatego też współczesny polski patriotyzm, pamiętając o wkładzie, jaki wnosi doń katolicyzm i polska

${ }^{24}$ Paweł Ciecieląg, Paweł Boryszewski. Zaangażowanie religijne. W: Jakość życia w Polsce 2015 r. Wyniki badania spójności społecznej. GUS. Warszawa 2017 s. 114.

${ }^{25}$ Egon Spiegel. Współczesne problemy i perspektywy pedagogiki religii. W: Barwy nauki. Nowoczesne technologie ICT w upowszechnianiu osiągnięć nauki. Red. Sławomir Nowosad, Bożena Żurek. Katolicki Uniwersytet Lubelski Jana Pawła II. Towarzystwo Naukowe KUL. Lublin 2010 s. $464-465$. 
tradycja, zawsze winien żywić szacunek i poczucie wspólnoty wobec wszystkich obywateli, bez względu na ich wyznanie czy pochodzenie, dla których polskość i patriotyzm są wyborem moralnym i kulturowym"26.

W warunkach globalizacji we współczesnym świecie zmienia się zarówno przynależność narodowa, jak i wyznaniowa (katolicka). Jak zauważa Edmund Wnuk-Lipiński, następuje relatywizacja tożsamości społecznych, a otwarcie się wspólnoty lokalnej na świat zmienia zasadniczo perspektywę, w której jednostki lokują zarówno siebie, jak i swoje bliższe i dalsze otoczenie. Zwiększa się liczba punktów odniesienia, jak i ich zakres, dzięki którym jednostki definiują siebie i innych. Także własny naród jest zaledwie jednym z możliwych punktów odniesienia w szerszym kontekście społeczności międzynarodowej. Upowszechnia się świadomość istnienia wielości systemów politycznych, wielości kultur i społeczeństw, co w konsekwencji prowadzi do relatywizacji relacji z własną wspólnotą narodową, traktowaną wcześniej jako „naturalne”, zastane i w istocie jedyne otoczenie społeczne, kształtujące tożsamość jednostek ${ }^{27}$.

Procesy globalizacyjne, związane także z procesami detradycjonalizacji, oddziałują nie tylko na wspólnotę narodową, ale i na wspólnotę katolicką. Związki między religią i tożsamością narodową mogą przybierać rozmaite postacie i mogą się różnicować nawet w obrębie tego samego narodu. Można ogólnie powiedzieć, że we współczesnej Europie zmniejszają się powiązania między tożsamością etniczną a religijnością, ale religia odgrywa wciąż bardzo istotną rolę w identyfikacjach na pograniczach etnicznych i narodowych, natomiast nie bywa już tak wyraźnie jak w przeszłości włączona jako składnik identyfikacji narodowej tych narodów, które posiadają stabilne narodowe państwa ${ }^{28}$.

Według niektórych prognoz może nastąpić wzrost w najbliższych dziesięcioleciach znaczenia religii i identyfikacji religijnych jako podstaw przeobrażeń tożsamości społecznych. „Hipoteza o możliwym wzroście znaczenia identyfikacji religijnej jako składnika tożsamości narodowej w miarę zaniku pewnych funkcji oraz zasad odrębności państw narodowych nie może być obecnie jeszcze empirycznie zweryfikowana. Mimo postępów integracji ponadpaństwowej w Europie teza o <rozmywaniu $>$ się państw narodowych nie wydaje się uzasadniona. Państwa te stanowią ciągle bardzo istotne podmioty oraz podstawy identyfikacji i poczucia odrębności narodowej”29.

Jan Paweł II w wywiadzie udzielonym dziennikarzowi i deputowanemu do Parlamentu Europejskiego Jasiowi Gawrońskiemu w 1993 roku podkreślił m. in., że

${ }^{26}$ Konferencji Episkopatu Polski. Chrześcijański kształt patriotyzmu. Wydawnictwo Diecezji Tarnowskiej Biblos. Tarnów 2017 s. 11.

${ }^{27}$ Edmunt Wnuk-Lipiński. Świat międzyepoki. Globalizacja, demokracja, państwo narodowe. Wydawnictwo ZNAK. Instytut Studiów Politycznych PAN. Kraków 2004 s. 219-220.

${ }^{28}$ Grzegorz Babiński. Religia i tożsamość narodowa - zmieniające się relacje. W: Religia i kultura w globalizującym się świece. Red. Marian Kempny, Grażyna Woroniecka. Zakład Wydawniczy NOMOS. Kraków 1999 s. 210-211.

29 Tamże s. 211. 
narody Europy Środowo-Wschodniej, mimo wszelkich transformacji narzuconych im przez reżimy komunistyczne, potrafiły zachować tożsamość narodową. Ideologii walki klas i dyktatury klasowej nie udało się pokonać świadomości narodowej ani świadomości religijnej. „Poczucie tożsamości narodowej i tożsamości religijnej pozostało nietknięte i w pewnym sensie się umocniło"30.

Poczucie dumy narodowej kształtowało się w Polsce na bardzo wysokim poziomie. W 2008 roku 50,4\% dorosłych Polaków identyfikowało się z własnym narodem w zdecydowany sposób, 45,5\% - raczej tak, 3,8\% - raczej nie, 0,9\% zdecydowanie nie. W latach 1989-2008 pozostawało ono na zbliżonym poziomie, chociaż wskaźnik odpowiedzi ,zdecydowanie tak” zmniejszył się od 68,6\% do $50,4 \%{ }^{31}$. Poczucie dumy „bycia Polakiem” w środowiskach młodzieżowych kształtowało się na znacznie niższym poziomie.

Młodzież uczęszczająca w 2016 roku do szkół ponadgimnazjalnych oceniła m. in. swój patriotyzm i przywiązanie do Ojczyzny. W całej zbiorowości $31 \%$ badanych deklarowało w zdecydowany sposób, że uważa siebie za patriotę, $42 \%$ - raczej tak, 13\% - raczej nie, $8 \%$ - zdecydowanie nie i 7\% - trudno powiedzieć. Za patriotów częściej uważali siebie uczniowie zasadniczych szkół zawodowych niż uczniowie z liceów ogólnokształcących (79\% wobec 69\%), znacznie częściej uczniowie o poglądach prawicowych niż lewicowych (83\% wobec $59 \%$ ), znacznie częściej głęboko wierzący niż niewierzący (84\% wobec 53\%). Ponad dwie trzecie badanych uczniów odczuwało często jedynie dumę, a bycie Polakiem lub Polką nie było dla nich źródłem wstydu (68\%), dla jednej czwartej ankietowanych $(25 \%)$ przynależność narodowa nie była źródłem żadnych emocji (,,ani duma, ani wstyd”); $5 \%$ badanych odczuwało tylko wstyd i $1 \%$ - dumę i wstyd. Młodzi Polacy są nastawieni mniej patriotycznie niż starsi ${ }^{32}$.

W zbiorowości maturzystów z Puław w 1994 roku 27,7\% badanych deklarowało zdecydowanie poczucie dumy z bycia Polakiem, 36,0\% - raczej tak, 6,2\% - raczej nie, $1,7 \%$ - zdecydowanie nie, $27,3 \%$ - brak zdania, $1,2 \%$ - brak odpowiedzi; w 2016 roku (odpowiednio) - 46,2\%, 34,6\%, 3,8\%, 2,1\%, 12,9\%, 0,3\%. Łącząc odpowiedzi ,zdecydowanie tak” i „raczej tak” otrzymujemy wskaźnik 63,7\% tych, którzy w 1994 roku deklarowali postawę patriotyczną, i 80,8\% - w 2016 roku (różnica 17,1\%). W latach 1994-2016 zmniejszyła się wyraźnie liczba maturzystów „niezdecydowanych” (o 14,4\%). Większość badanych maturzystów wyrażała dumę $\mathrm{z}$ faktu bycia Polakiem.

${ }^{30}$ W czym oddaliliśmy się od Ewangelii? Koniec drugiego tysiącleci wymaga rachunku sumienia. „L' Osservatore Romano” 15: 1994 nr 1 s. 25.

31 Aleksandra Jasińska-Kania. Dynamika zmian wartości Polaków na tle europejskim: EVS 1990 - 1999 - 2008. W: Polska po 20 latach wolności. Red. Marta Bucholc, Sławomir Mandes, Tadeusz Szawiel, Joanna Wawrzyniak. Wydawnictwa Uniwersytetu Warszawskiego. Warszawa 2011 s. 236-237.

32 Antoni Głowacki. Patriotyzm, nacjonalizm i stosunek do obcych. W: Młodzież 2016. Raport z badania sfinansowanego przez Krajowe Biuro ds. Przeciwdziałania Narkomanii. CBOS. Warszawa 2016 s. 114-117. 
Kobiety częściej niż mężczyźni deklarowały poczucie dumy narodowej $(84,5 \%$ wobec 75,4\%); młodzież z liceów ogólnokształcących rzadziej niż z techników (70,3\% wobec 90,5\%); młodzież ze wsi i małych miast częściej niż z miast liczących powyżej 20 tys. mieszkańców, głównie z Puław (89,3\% wobec 67,0\%); wierzący (90,4\%) częściej niż niezdecydowani w sprawach wiary - 77,1\%, obojętni religijnie - 58,1\% i niewierzący - 55,5\%; praktykujący w każdą niedzielę lub częściej $(87,2 \%)$ i praktykujący dwa lub trzy razy w miesiącu $(92,5 \%)$ częściej niż praktykujący raz w miesiącu lub rzadziej $(84,8 \%)$ i w ogóle niepraktykujący $(55,6 \%)$.

Nastąpił wzrost postaw patriotycznych przy znacznym zmniejszeniu się liczby tych, którzy nie potrafili określić swoich poczuć narodowych ${ }^{33}$. Potwierdza się konstatacja z dokumentu Konferencji Episkopatu Polski o patriotyzmie, że w ostatnich latach obserwujemy w Polsce ożywienie postaw patriotycznych i poczucia świadomości narodowej. Jeżeli nawet patriotyzm jako wartość deklarowana znajduje się dość nisko w hierarchii spraw życia codziennego, to trzeba podkreślić, że pojęcie to jest nadal obecne w życiu ludzi młodych. Postawy patriotyczne (duma bycia Polakiem) częściej deklarowały kobiety, młodzież z techników, osoby mieszkające na wsi lub w małych miastach, wierzące i praktykujące.

Badanym maturzystom przedstawiono do oceny następujące twierdzenie: „dobry Polak to katolik". Respondenci mogli ustosunkować się do niego w jeden z pięciu sposobów: od „zdecydowanie tak” do „zdecydowanie nie”. Mogli też zawiesić swój sąd i nie zająć stanowiska w omawianej sprawie. W całej zbiorowości maturzystów puławskich w 1994 roku 1,7\% badanych opowiedziało się w zdecydowany sposób za twierdzeniem, że „dobry Polak to katolik”, 12,0\% - raczej tak, 27,3\% - raczej nie, $35,5 \%$ - zdecydowanie nie, $22,7 \%$ - brak zdania na ten temat, $0,8 \%$ - brak odpowiedzi; w 2009 roku (odpowiednio) - 8,8\%, 27,6\%, 26,8\%, 18,8\%, 16,0\%, $2,0 \%$; w $2016-4,9 \%, 24,1 \%, 19,2 \%, 25,9 \%, 24,1 \%, 1,7 \%$.

Pogląd o nierozerwalnym powiązaniu polskości z katolicyzmem uznawało w 1994 roku 13,7\% badanych, w 2009 roku - 36,4\%, w 2016 roku-29,0\%. W 2016 roku około co piąty ankietowany był zaskoczony tym pytaniem i twierdził, że nie ma zdania w tej sprawie lub w ogóle nie zastanawiał się nad tą kwestią. Podobne wyniki uzyskano w innych badaniach socjologicznych. W całej zbiorowości maturzystów lubelskich w roku szkolnym 2009/2010 tylko 6,1\% badanych opowiedziało się w zdecydowany sposób za twierdzeniem, że dobry Polak to katolik, 27,9\% raczej tak, 23,2\% - raczej nie, 18,1\% - zdecydowanie nie, 24,2\% - trudno powiedzieć i $0,6 \%$ - brak odpowiedzi. Pogląd o nierozerwalnym powiązaniu polskości i katolicyzmu podzielało $34,0 \%$ ogółu badanych maturzystów ${ }^{34}$.

${ }^{33}$ Janusz Mariański. Patriotyzm i religia jako wartości podstawowe w świadomości polskich maturzystów. „Studia Płockie” 25: 1997 s. 180-183.

${ }^{34}$ Marcin Rola. Wartości moralne w świadomości maturzystów lubelskich. Studium socjologiczne. Wydawca i druk Drukarnia Standruk. Lublin 2016 s. 123-125. 
W 2016 roku kobiety nieco częściej niż mężczyźni deklarowały nierozłączność polskości i katolicyzmu (31,0\% wobec 26,2\%), uczniowie z liceów ogólnokształcących rzadziej niż z techników $(21,7 \% \%$ wobec $35,8 \%)$, młodzież mieszkająca na wsi i w małych miastach częściej niż w miastach powyżej 20 tys. mieszkańców (36,7\% wobec $16,6 \%)$, wierzący $(40,1 \%)$ częściej niż niezdecydowani w sprawach wiary $(23,0 \%)$, obojętni religijnie $(3,2 \%)$ i niewierzący $(0,8 \%)$, praktykujący w każdą niedzielę lub częściej $(41,4 \%)$ i praktykujący dwa lub trzy razy w miesiącu (41,5\%) częściej niż praktykujący raz w miesiącu lub rzadziej $(27,7 \%)$ i w ogóle niepraktykujący (3,7\%).

Zbitkę pojęciową „Polak - katolik” częściej akceptowały kobiety, młodzież z techników, osoby mieszkające na wsi lub w małych miastach, wierzące i praktykujące. Stereotypowe wyobrażenia „Polak - katolik” są jeszcze stosunkowo żywotne wśród osób głęboko wierzących, słabną wraz z przechodzeniem do wierzących, niezdecydowanych w sprawach wiary oraz praktycznie nie istnieją wśród obojętnych religijnie i niewierzących. We wszystkich wyróżnionych kategoriach badanych osób uznający określenie „Polak - katolik” są w wyraźnej mniejszości. Dla nich polskość kojarzy się jeszcze - niekiedy automatycznie - z katolickością.

W latach 1994-2009 nastąpił znaczny zrost wskaźnika tych, którzy w zdecydowany lub umiarkowany sposób aprobowali związek pomiędzy polskością i katolicyzmem. W latach 2009-2016 nastąpił pewien regres stereotypowych wyobrażeń o nierozłącznym związku polskości i katolicyzmu, ale nie osiągnął on poziomu akceptacji z 1994 roku. Aktualnie nieco częściej niż co czwarty ankietowany maturzysta podtrzymuje pogląd, że dobry Polak to katolik. Tożsamość narodowa nie splata się już tak silnie jak dawniej z identyfikacją religijną (katolicką). W społeczeństwie pluralistycznym zaczynają słabnąć związki katolickości i polskości, a ci, którzy ten związek aprobują, są w środowiskach młodzieżowych w mniejszości.

\section{AUTOIDENTYFIKACJE RELIGIJNE MATURZYSTÓW PUŁAWSKICH}

Autoidentyfikacje religijne obejmują najczęściej utożsamienie się ze wspólnotą wierzących, dynamikę ogólnych postaw wobec religii w porównaniu z okresem dzieciństwa lub młodości albo w porównaniu z rodzicami, uzasadnienie własnej wiary lub niewiary. Badanie tzw. globalnych postaw wobec wiary (głęboko wierzący, wierzący, niezdecydowany, obojętny, niewierzący) tylko w ogromnym przybliżeniu i wstępnie charakteryzuje religijność. Kryterium globalnych wyznań wiary nie informuje o wierności religii, ani o istotnej więzi z Kościołem, ale świadczy jedynie o woli zaliczenia się do zbiorowości ludzi określających się jako katolicy lub wierzący. Nie pozwala ono na uchwycenie pozakościelnej i zindywidualizowanej (prywatna, ukryta, mozaikowa, implicite, rozproszona, pozainstytucjonalna, 
nieusystematyzowana, powierzchowna, niesprecyzowana, „składanka religijna”, „majsterkowiczów”, „eksperymentatorów”, „kompozytorów”) religijności. Deklaracja przynależności do wspólnoty wyznaniowej lub też deklaracja stosunku do instytucji religijno-kościelnej, deklaracja typu ,jestem wierzący” pozwala na socjologiczne ujęcie orientacji i postaw wobec religii w wymiarach najbardziej ogólnych ${ }^{35}$.

Według sondażu CBOS z lutego 2015 roku 8,1\% badanych dorosłych Polaków deklarowało się jako głęboko wierzący, 80,7\% - jako wierzący, 6,4\% - jako raczej niewierzący, 3,5\% - jako całkowicie niewierzący, 1,3\% - trudno powiedzieć lub odmowa odpowiedzi; w kwietniu 2015 roku (odpowiednio) - 7,2\%, 82,2\%, 5,8\%, $3,3 \%, 1,5 \%$; w maju 2015 roku - 7,4\%, 82,2\%, 6,0\%, 3,3\%, 1,1\%; w październiku 2016 roku $-11,1 \%, 81,0 \%, 3,3 \%, 2,8 \%, 1,8 \%$, w grudniu 2016 roku $-6,5 \%, 83,9 \%$, $5,3 \%, 2,9 \%, 1,5 \%$; w styczniu 2017 roku - 9,2\%, 84,1\%, 3,1\%, 2,4\%, 1,1\% (dane uzyskane w CBOS). W lutym 2015 roku wskaźnik głęboko wierzących i wierzących po raz pierwszy nie przekroczył $90 \%(88,8 \%)$. Jeżeli nawet autodeklaracje religijne pozostają $\mathrm{w}$ społeczeństwie polskim na relatywnie wysokim poziomie, to jednak od kilku lat konstatujemy powolny przyrost tych, którzy deklarują się jako raczej lub zdecydowanie niewierzący. W styczniu 2017 roku wskaźnik głęboko wierzących i wierzących znowu przekroczył $90 \%$.

W badaniach ogólnopolskich zrealizowanych przez GUS w 2015 roku wśród ludności polskiej będącej w wieku 16 lat i więcej 10,5\% ankietowanych zadeklarowało się jako głęboko wierzący, 69,6\% - jako wierzący, $12,0 \%$ - jako niezdecydowani lub poszukujący, 5,3\% - jako obojętni w sprawach wiary, 2,6\% - jako niewierzący; wśród badanych będących w wieku 16-24 lata (odpowiednio) - 3,6\%, 69,0\%, 18,1\%, $6,7 \%, 2,6 \%{ }^{36}$. Wskaźnik wierzących kształtował się na poziomie $80,1 \%$ dla ogółu ludności i 72,6\% dla badanych w wieku 16-24 lata.

Można przypuszczać, że w środowiskach młodzieżowych wskaźniki pozytywnych postaw wobec religii będą kształtować się na niższym poziomie. W latach 2005-2014 - według sondaży CBOS - wśród ludzi młodych będących w wieku 18-24 lata odsetek głęboko wierzących utrzymywał się na stabilnym poziomie, ubyło zaś wierzących (spadek z 86\% do 77\%), wzrosła natomiast liczba tych, którzy określali siebie jako niewierzący (z 6\% do $15 \%)^{37}$. Z trzech badań ogólnopolskich zrealizowanych w latach 1988-1998-2005 przez Instytut Statystyki Kościoła Katolic-

35 Według badań zrealizowanych w 2007 roku przez Centrum Myśli Jana Pawła II w Warszawie $74 \%$ młodych Polaków deklarowało się jako osoby głęboko wierzące, $46 \%$ - jako osoby przywiązane do wartości katolickich i 60\% - jako przedstawiciele pokolenia JP 2. Piotr Dardziński. Religijny potencjał młodego pokolenia. W: Portret młodego pokolenia. Red. Michał Łuczewski. Instytut Badań nad Gospodarką Rynkową. Gdańsk 2009 s. 35.

36 Paweł Ciecieląg, Paweł Boryszewski. Zaangażowanie religijne. W: Jakość życia w Polsce 2015 r. Wynik badania spójności społecznej. GUS. Warszawa 2017 s. 116.

37 Rafał Boguszewski. Zmiany podstawowych wskaźników religijności po śmierci Jana Pawła II. W: Religijność i Kościół 10 lat po śmierci Jana Pawła II. Red. Mirosława Grabowska. CBOS. Warszawa 2015 s. 41. 
kiego SAC wynika, że wskaźnik głęboko wierzących i wierzących wśród uczniów i studentów polskich kształtował się odpowiednio: 80\%,68\%,70\% ${ }^{38}$.

Wśród uczniów ostatnich klas szkół ponadgimnazjalnych w 2016 roku 8\% badanych deklarowało się jako głęboko wierzący, 61\% - jako wierzący, 18\% jako niezdecydowani i 13\% - jako niewierzący; w 1996 roku (odpowiednio) - 6\%, 74\%, 14\%, 5\%. W 1996 roku łączny wskaźnik głęboko wierzących i wierzących kształtował się na poziomie 80\%, w 2016 roku - 69\% (różnica 11\%). Mimo stałego spadku odsetka deklarujących wiarę religijną w dalszym ciągu zdecydowana większość młodych ludzi uważa się za osoby wierzące: 68\% - wśród chłopców i 71\% - wśród dziewcząt; 76\% - wśród mieszkających na wsi i 60\% - w miastach powyżej 500 tys. mieszkańców; 67\% - wśród uczniów z liceów ogólnokształcących, $71 \%$ - z techników i $69 \%$ - z zasadniczych szkół zawodowych. Największa część ankietowanych wierzy w Boga i nie ma wątpliwości co do jego istnienia (42\%); $26 \%$ - wierzy w Boga, choć ma niekiedy chwile zwątpienia; $9 \%$ - czasami wydaje mi się, że wierzę w Boga, a czasami, że nie wierzę; 7\% - nie wierzę w osobowego Boga, ale wierzę w pewnego rodzaju Siłę Wyższą; $9 \%$ - nie wiem, czy Bóg istnieje i nie wierzę, że jest sposób, aby to sprawdzić; $8 \%$ - nie wierzę w Boga ${ }^{39}$.

Porównamy te wyniki empiryczne $\mathrm{z}$ danymi uzyskanymi w latach 1994-2016 wśród maturzystów puławskich. W 1994 roku 6,6\% badanych maturzystów określiło siebie jako głęboko wierzących, $60,3 \%$ - jako wierzących, $21,9 \%$ - jako niezdecydowanych w sprawach wiary, 7,9\% - jako obojętnych religijnie, $2,1 \%$ - jako niewierzących i 1,2\% - to nieudzielający odpowiedzi; w 2009 roku (odpowiednio) - 11,6\%, $50,8 \%, 20,8 \%, 9,6 \%, 3,6 \%, 3,6 \%$; w 2016 roku $-5,9 \%, 55,9 \%, 16,8 \%, 10,8 \%, 9,4 \%$, $1,2 \%$. Wskaźnik głęboko wierzących i wierzących kształtował się w 1994 roku na poziomie $66,9 \%$, w 2009 roku - 62,4\%, w 2016 roku - 61,8\%. Różnica między formalną przynależnością do katolicyzmu a deklarowaną identyfikacją wiary jest znaczna (około 20\%). Wskaźnik przynależności religijnej („wierzący”) znacznie oddalił się od tzw. oczywistości kulturowej i w ostatnich latach zmniejszył się tylko nieznacznie. Na zbliżonym poziomie pozostał wskaźnik niezdecydowanych w sprawach wiary. Fakt, że około piąta część badanych maturzystów przyjmuje taką postawę świadczy, że w tej kwestii nie posiadają oni sprecyzowanych poglądów. Dość wyraźnie wzrosły odsetki obojętnych religijnie i niewierzących: w 1994 roku $-10,0 \%$, w 2009 roku - 13,0\%, w 2016 roku - 20,2\%. Obojętni religijnie, a zwłaszcza niewierzący, nie czują już kwestii religijnych, niechętnie uczestniczą w życiu parafialnym, nie są zainteresowani jakąkolwiek działalnością kościelną.

Nieco wyższe wyniki empiryczne uzyskano w innych badaniach socjologicznych zrealizowanych na Lubelszczyźnie. Wśród młodzieży maturalnej w roku szkolnym

${ }^{38}$ Sławomir H. Zaręba. Identyfikacje religijne i dylematy moralne uczniów i studentów w Polsce. „Collectanea Theologica” 79: 2009 nr 1 s. 168.

39 Antoni Głowacki. Religijność młodzieży. W: Młodzież 2016. Raport z badania sfinansowanego przez Krajowe Biuro ds. Przeciwdziałania Narkomanii. CBOS. Warszawa 2016 s. 131-139. 
2009/2010 w Lublinie 8,5 \% badanych uznawało siebie za głęboko wierzących, 60,3 \% - za wierzących (wskaźnik wierzących ogółem - 68,8\%), 19,6 \% - za niezdecydowanych ale przywiązanych do tradycji religijnej, 9,2\% - za obojętnych w sprawach religijnych i 2,4 \% - za niewierzących. Kobiety w 73,0 \% uznawały się za głęboko wierzących lub wierzących, mężczyźni - w 64,1 \%; uczniowie liceów ogólnokształcących $-72,6 \%$, techników $-65,7 \%$, liceów profilowanych $60,0 \%$; mieszkający na wsi $-73,2 \%$, w miastach do 100 tys. mieszkańców - 59,6 $\%$, w miastach powyżej 100 tys. mieszkańców - 68,9\%. Maturzyści lubelscy wykazywali - według własnych deklaracji - wyższy poziom zgodności poglądów w sprawach wiary z matkami niż z ojcami ${ }^{40}$.

Wśród maturzystów z woj. lubelskiego w 2010 roku 65,4 \% badanych określiło siebie jako wierzących, 19,0\% - jako niezdecydowanych ale przywiązanych do tradycji religijnych, 7,6 \% - jako obojętnych, 7,6\% - jako niewierzących i $0,5 \%$ to nieudzielający odpowiedzi. Kobiety częściej niż mężczyźni deklarowały swoją wiarę religijną (69,9\% wobec 59,8 \%). W ocenie respondentów ich matki częściej niż ojcowie są wierzącymi $(68,2 \%$ wobec 49,3$)$. W całej zbiorowości maturzystów $71,5 \%$ uznało religię za ważną wartość w życiu, 13,7 \% - za niezbyt ważną, 13,1 $\%$ - za nieważną, 1,6 \% - brak odpowiedzi; $60,6 \%$ ankietowanych wyraziło gotowość bronienia wiary za cenę życia ${ }^{41}$.

Młodzież licealna z Puław w 2012 roku określiła swój stosunek do religii w następujący sposób: głęboko wierzący - 10,5 \%, wierzący - 51,3 \%, niezdecydowany $-19,9 \%$, obojętny $-7,3 \%$, niewierzący $-5,8 \%$, brak odpowiedzi $-5,2 \%{ }^{42}$. W badaniach ankietowych przeprowadzonych w latach 2014-2015 wśród uczniów klas drugich liceów ogólnokształcących i techników z terenu Lubelszczyzny 11,22\% ankietowanych deklarowało się jako głęboko wierzący, 61,45\% - jako wierzący, $17,85 \%$ - jako niezdecydowani ale przywiązani do tradycji religijnej, $5,77 \%$ - obojętni, $3,71 \%$ - jako niewierzący ${ }^{43}$.

W zbiorowości maturzystów puławskich w 2016 roku kobiety częściej niż mężczyźni uznawały siebie za osoby głęboko wierzące lub wierzące $(69,9 \%$ wobec $52,1 \%)$, maturzyści z liceów ogólnokształcących rzadziej niż techników (59,4\% wobec $65,5 \%$ ), mieszkający na wsi i w małych miastach częściej niż w miastach powyżej 20 tys. mieszkańców (70,3\% wobec 50,0\%), praktykujący w każdą niedzielę i niekiedy w dni powszednie $(85,7 \%)$ i praktykujący dwa lub trzy razy w miesiącu

${ }^{40}$ Marcin Rola. Wartości moralne w świadomości maturzystów lubelskich. Studium socjologiczne. Wydawca i druk Drukarnia Standruk. Lublin 2016 s. 126-129 .

${ }^{41}$ Ewa Miszczak. Świętość w religijnej świadomości maturzystów województwa lubelskiego. Studium socjologiczne. Wydawnictwo UMCS. Lublin 2014 s. 141 i 350.

${ }^{42}$ Ewa Panecka. Środowiskowe uwarunkowania zachowań altruistycznych młodzieży licealnej. Lublin 2015 (mps pracy doktorskiej) s. 254.

${ }^{43}$ Krzysztof Podstawka. Młodzież Lubelszczyzny wobec wartości moralnych. W: Edukacja w perspektywie oczekiwań współczesności. Red. Anna Karpińska, Katarzyna Borawska-Kalbarczyk, Alina Szwarc. Wydawnictwo Adam Marszałek. Toruń 2016 s. 300. 
(90,6\%) częściej niż praktykujący raz w miesiącu lub kilka razy w roku $(58,7 \%)$ i w ogóle niepraktykujący (11,3\%). Przynależność religijną (wierzący) częściej deklarowały kobiety, młodzież uczęszczająca do techników, mieszkająca na wsi lub w małych miastach i praktykująca regularnie lub prawie regularnie.

Stosunkowo niski wskaźnik autodeklaracji religijnych wśród młodzieży jest - być może - częściowo spowodowany samą konstrukcją pytania, w którym umieszczono odpowiedź „niezdecydowany, ale przywiązany do tradycji religijnych”. Młodzież szkolna, która jest w fazie kształtowania swojego indywidualnego światopoglądu religijnego lub laickiego, w fazie usensownienia życia i odnajdywania dla siebie miejsca w otaczającym ją świecie, stosunkowo często określała swój „stan ducha” jako niezdecydowanie, nawet wtedy, gdy de facto uznawała istnienie Boga i niektóre wierzenia religijne (niechęć do informowania o swojej przynależności religijnej). Jest to jednak wiara dwuznaczna, niekonsekwentna, pomieszana z podejrzeniami i powątpiewaniem. Dość upowszechnione w środowiskach młodzieżowych postawy zwątpienia i niezdecydowania oraz pozostawanie w sytuacji nieokreśloności religijnej, pewnej fasadowości i powierzchowności, mogą być wyraźnym sygnałem osłabienia procesów ożywienia religijnego z lat osiemdziesiątych XX wieku oraz zacierania się konturów wiary i niewiary. Fakt, że około trzecia część młodzieży szkolnej nie zdołała określić siebie jako wierzącą, jest znamienny. Może on świadczyć o powolnej sekularyzacji środowisk młodzieżowych w Polsce (scenariusz sekularyzacji).

Dane empiryczne dotyczące autoidentyfikacji religijnej wskazują, że w środowiskach młodzieżowych ateiści, agnostycy i indyferenci nie wymarli, ale też za wcześnie uderzać w żałobne dzwony dla katolicyzmu. Religijna obojętność lub niewiara stanowią podstawę wyjścia z Kościoła. Określający siebie jako „niezdecydowani w sprawach wiary" oscylują między wiarą i niewiarą. Swoją postawę wobec religii formułują często w słowach: „Być może wierzę”; „Czemu nie”; „Przy okazji”; „Coś jest, ale nie wiem co”; „Wierzę w Boga a nie w księdza”; „Wierzę w samego siebie”, „Być może, ale nie jestem pewien”; „Mam wątpliwości”; „Nie wiem”. Taka religijność jest z pewnością religijnością osobistą, ale niekoniecznie osobową. Nie zawsze wyraża się ona wiarą w Boga osobowego i nie oznacza uznania wszystkich podstawowych dogmatów chrześcijaństwa ${ }^{44}$.

Wśród osób „niezdecydowanych, ale przywiązanych do tradycji religijnej”, są maturzyści, którzy w rzeczywistości są wierzącymi na swój sposób, choć sami nie określają siebie jako religijnych. Jeżeli uznalibyśmy przytoczone powyżej wyniki za odzwierciedlające w przybliżony sposób faktyczne postawy młodzieży wobec religii, można by wówczas mówić o powstającej powoli „przepaści” pokoleniowej czy „,rozdźwięku” pokoleń w zakresie globalnych ustosunkowań się do religii. Spadek wskaźnika wierzących wśród młodzieży stanowi nowy trend w fazie przemian

${ }^{44}$ Teraźniejszość i przyszłość religii w Europie Zachodniej. „Chrześcijanin w Świecie” 17: 1985 nr 6 s. 33. 
ustrojowych i niewątpliwie swoiste zjawisko towarzyszące tym przemianom ${ }^{45}$. Trudno przewidzieć, czy aktualnie deklarowany dystans wobec religii zaznaczający się u części maturzystów utrzyma się w przyszłości, czy raczej się jeszcze pogłębi. Wyniki uzyskane wśród maturzystów puławskich pozwalają przypuszczać, że trend spadkowy będzie kontynuowany. Procesy sekularyzacyjne przebiegają jednak w zróżnicowany sposób w rozmaitych środowiskach społecznych ${ }^{46}$.

\section{AUTOIDENTYFIKACJE PRAKTYK RELIGIJNYCH}

Praktyki religijne są ważnym wskaźnikiem religijności w jej wymiarach indywidualnych i społecznych. Religijność wyraża się w konkretnych działaniach, bez nich byłaby rodzajem światopoglądu, filozofii czy ideologii. W badaniach socjologicznych praktyki religijne należą do często stosowanych pomiarów zinstytucjonalizowanej religijności (tzw. kościelność). Praktyki religijne są ważnym czynnikiem współokreślającym postawy prospołeczne i zaangażowanie w różne formy aktywności społecznej. Wraz z kryzysem praktyk religijnych przychodzi często kryzys samej religijności jako postawy dialogu człowieka z Bogiem. Bez praktyk religijnych i odkrycia ich roli w życiu codziennym, wiara jest narażona na utratę świeżości i zaniedbanie ${ }^{47}$.

Socjologowie często podkreślają społeczno-kulturowy charakter polskiego katolicyzmu. Powszechność wierzeń i praktyk religijnych usprawiedliwiała twierdzenie, że religia jest dla Polaków przede wszystkim wartością wspólną, odświętną i zewnętrzną, w mniejszym zakresie zaś wartością osobistą, przeżywaną i wewnętrzną. Faktem jest, że bycie katolikiem i poniekąd także katolikiem praktykującym było swoistą normą kulturową. W świetle dotychczasowych badań socjologicznych praktyki religijne katolików odznaczały się stabilnością, w latach osiemdziesiątych XX wieku nastąpił ich nieznaczny wzrost, w latach dziewięćdziesiątych nieznaczny spadek. Autodeklaracje praktyk religijnych wskazywały na ich relatywnie wysoki poziom, tak w środowiskach młodzieżowych, jak i w całym społeczeństwie. Odzwierciedlały one na ogół poziom uczestnictwa w niedzielnej mszy św.

Od 2013 roku wskaźnik uczęszczających w każdą niedzielę do kościoła spadał poniżej 50\%. Według sondażu CBOS z czerwca 2014 roku 4,2\% dorosłych Polaków

${ }^{45}$ Kazimierz Święs. Obraz współczesnej młodzieży w Polsce. „Warszawskie Studia Pastoralne UKSW" 9: 2014 nr 2 s. 41-44.

${ }^{46}$ Carsten Gennerich, Andreas Feige. Jugend und Religion in neuer Perspektive: Empirisch valide Forschungsergebnisse durch eine theoretisch angemessene Fundierung. „International Journal of Practical Theology" 2009 nr 3 s. 25-26.

${ }^{47}$ Franco Floris. Modlitwa (wychowanie do modlitwy). W: Słownik katechetyczny. Tł. Krystyna Kozak. Wydawnictwo Salezjańskie. Warszawa 2007 s. 607. 
deklarowało, że zazwyczaj bierze udział w takich praktykach religijnych jak: msze, nabożeństwa czy spotkania religijne kilka razy w tygodniu, 46,6\% - raz w tygodniu, $16,5 \%$ - przeciętnie jeden lub dwa razy w miesiącu, 20,2\% - kilka razy w roku, $12,6 \%$ - w ogóle w nich nie uczestniczy; w lutym 2015 roku (odpowiednio) - 3,5\%, $46,1 \%, 14,7 \%, 22,9 \%, 11,7 \%$ (oraz 1,1\% - brak odpowiedzi); w marcu 2015 roku $-4,3 \%, 42,0 \% 18,6 \%, 21,6 \%, 12,3 \%(1,2 \%)$; w sierpniu 2015 roku $-3,8 \%, 40,7 \%$, $13,6 \%, 23,1 \%, 16,9 \%$ (1,8\%); w listopadzie 2015 roku $-5,1 \%, 43,6 \%, 14,3 \%, 22,1 \%$, $14,1 \%(0,8 \%)$; w lipcu 2016 roku $-5,7 \%, 41,7 \%, 16,9 \%, 22,4 \%, 12,5 \%$ (0,8\%); w październiku 2016 roku - 6,4\%, 46,9\%, 15,5\%, 21,3\%, 8,2\% (1,6\%); w grudniu 2016 roku $-4,9 \%, 37,3 \%, 18,1 \%, 25,6 \%, 12,5 \%$ (1,5\%); w styczniu 2017 roku - 3,9\%, $42,6 \%, 17,3 \%, 24,7 \%, 10,5 \%$ (0,9\%) (dane uzyskane w CBOS).

W drugiej połowie pierwszej dekady XXI wieku zaczęły się powoli zmniejszać odsetki osób przyznających się do regularnego uczestnictwa w praktykach religijnych, powoli wzrastały odsetki praktykujących nieregularnie (okazjonalnie) i w ogóle niepraktykujących. Zmiany te były szczególnie widoczne w środowiskach młodzieżowych. W latach 2005-2013 wśród respondentów w wieku 18-24 lata, badanych w ramach prób ogólnopolskich obejmujących dorosłych Polaków, znacząco ubyło osób regularnie praktykujących (od 51\% do 43\%), a przybyło niepraktykujących (od 10\% do 18\%). Wskaźnik nieregularnie uczęszczających do kościoła pozostawał na zbliżonym poziomie (około $39 \%)^{48}$.

W badaniach ogólnopolskich zrealizowanych przez GUS w 2015 roku ustalono, że 4,0\% ankietowanych będących w wieku 16 lat i więcej deklarowało uczestnictwo we mszach lub nabożeństwach codziennie lub częściej niż raz w tygodniu, $45,4 \%$ - raz w tygodniu, 18,2\% - jeden lub dwa razy w miesiącu, 19,9\% - tylko z okazji świąt, 6,4\% - jeszcze rzadziej, 6,1\% - nigdy; badani w wieku 16-24 lata (odpowiednio) - 1,6\%, 38,4\%, 18,1\%, 29,4\%, 5,9\%, 6,6\% ${ }^{49}$. We mszach św. lub nabożeństwach uczestniczyło przynajmniej raz w tygodniu 49,4\% ogółu badanych Polaków i 40,0\% - ankietowanych będących w wieku 16-24 lata.

Wśród uczniów ostatnich klas szkół ponadgimnazjalnych w 2016 roku 8\% ankietowanych deklarowało, że bierze udział w praktykach religijnych takich jak msze, nabożeństwa lub spotkania religijne kilka razy w tygodniu, 32\% - raz w tygodniu, 9\% - przeciętnie jeden lub dwa razy w miesiącu, 21\% - kilka razy w roku i 29\% - w ogóle w nich nie uczestniczy; w 1998 roku (odpowiednio) - 6\%, $48 \%, 10 \%, 19 \%, 16 \%$; w 2013 roku - 6\%, 37\%, 13\%, 21\%, 23\%. W latach 1998 2016 wskaźnik uczestniczących regularnie (w każdą niedzielę) w praktykach religijnych zmniejszył się od 54\% do 40\% (różnica 14\%). Wynosił on 77\% wśród

${ }^{48}$ Rafał Boguszewski. Od zinstytucjonalizowanej do zindywidualizowanej: religijność Polaków w procesie przemian. W: Globalny i lokalny wymiar religii. Polska w kontekście europejskim. Red. Irena Borowik, Andrzej Górny, Wojciech Świątkiewicz. Zakład Wydawniczy NOMOS. Kraków 2016 s. 140.

49 Paweł Ciecieląg, Paweł Boryszewski. Zaangażowanie religijne. W: Jakość życia w Polsce 2015 r. Wynik badania spójności społecznej. GUS. Warszawa 2017 s. 116-117. 
głęboko wierzących, 51\% - wśród wierzących, 16\% - wśród niezdecydowanych i 7\% - wśród niewierzących; wśród chłopców - 39\%, wśród dziewcząt - 43\%; wśród mieszkających na wsi - 47\%, w miastach powyżej 500 tys. mieszkańców - 23\%; wśród uczniów z liceów ogólnokształcących - 45\%, z techników - 42\%, z zasadniczych szkół zawodowych $-31 \%{ }^{50}$.

Badania socjologiczne zrealizowane wśród maturzystów w Puławach w 2016 roku i w innych środowiskach młodzieżowych naszego kraju wskazują na spadek uczestnictwa w niedzielnej mszy św. W 1994 roku w Puławach 17,8\% badanych maturzystów deklarowało, że uczestniczy we mszy św. w niedzielę i niekiedy w dni powszednie, $27,3 \%$ - w każdą niedzielę, $24,4 \%$ - od jeden do trzech razy w miesiącu, 20,7\% - kilka razy w roku, 7,9\% - w ogóle niepraktykuje, 2,0\% - brak odpowiedzi; w 2009 roku (odpowiednio) - 10,8\%, 20,4\%, 30,8\%, 25,2\%, 9,2\%, 3,6\%; w 2016 roku - 9,4\%, 15,0\%, 27,9\%, 27,3\%, 18,9\%, 1,4\%. Wskaźnik uczęszczających w każdą niedzielę lub niekiedy częściej kształtował się w 1994 roku na poziomie 45,1\%, w 2009 roku - 31,2\%, w 2016 roku - 24,4\%.

Wśród kobiet praktykujących w każdą niedzielę a niekiedy i w dni powszednie wynosił 27,7\%, wśród mężczyzn - 20,7\%. Uczniowie szkół ogólnokształcących praktykowali częściej niż uczniowie z techników (32,4\% wobec 17,8\%), mieszkający na wsi i w małych miastach $(28,0 \%)$ częściej niż w miastach powyżej 20 tys. mieszkańców $(19,6 \%)$, głęboko wierzący i wierzący $(34,3 \%)$ częściej niż niezdecydowani (12,5\%), obojętni religijnie $(6,7 \%)$ i niewierzący $(7,4 \%)$. Kobiety praktykują regularnie częściej niż mężczyźni (różnica 7,0\%), uczniowie z liceów ogólnokształcących częściej niż z techników (14,6\%), mieszkający na wsi i w małych miastach częściej niż w miastach powyżej 20 tys. mieszkańców (różnica 8,4\%), wierzący częściej niż niewierzący (różnica 26,9\%).

Nieco odmienne wyniki uzyskano w innych badaniach socjologicznych w regionie lubelskim. Wśród maturzystów lubelskich w roku szkolnym 2009/2010 - 17,0\% praktykowało w każdą niedzielę i czasami w dni powszednie, $24,2 \%$ - w każdą niedzielę, 19,9\% - dwa lub trzy razy w miesiącu, 6,6\% - raz w miesiącu, 23,8\% - kilka razy w roku, $8,1 \%$ - w ogóle nie praktykuje, $0,4 \%$ - brak odpowiedzi. Kobiety częściej niż mężczyźni deklarowały udział w niedzielnej mszy św., młodzież z liceów ogólnokształcących częściej niż z techników i liceów profilowanych, młodzież mieszkająca na wsi częściej niż w miastach. Wśród osób deklarujących się jako głęboko wierzący $84,8 \%$ praktykowało przynajmniej raz w miesiącu, wśród wierzących $-81,7 \%$, wśród niezdecydowanych ale przywiązanych do tradycji religijnych $-51,9 \%$, wśród obojętnych w sprawach religijnych lub niewierzących $-9,5 \% \%^{51}$.

${ }^{50}$ Antoni Głowacki. Religijność młodzieży. W: Młodzież 2016. Raport z badania sfinansowanego przez Krajowe Biuro ds. Przeciwdziałania Narkomanii. CBOS. Warszawa 2016 s. 133-140.

${ }^{51}$ Marcin Rola. Wartości moralne w świadomości maturzystów lubelskich. Studium socjologiczne. Wydawca i druk Drukarnia Standruk. Lublin 2016 s. 132-133. 
Wśród maturzystów z woj. lubelskiego w 2010 roku 46,2 \% badanych informowało, że bierze udział regularnie w niedzielnej mszy św. (w każdą lub prawie w każdą niedzielę), 42,3\% - nieregularnie (od czasu do czasu), 10,6\% - brak praktyk religijnych od kilku lat, 0,3\% - w ogóle nie praktykuje, $0,6 \%$ - brak odpowiedzi. Regularne uczestnictwo w praktykach niedzielnych deklarowało 53,0 \% kobiet i 37,4 \% - mężczyzn; 56,5\% - uczniów z liceów ogólnokształcących, 34,3 $\%$ - z liceów profilowanych i 33,4 \% - z techników; 50,4 \% - mieszkających na wsi, 47,3\% - w małym mieście, 43,8 \% - w średnim mieście i 31,5\% - w dużym mieście. Osoby deklarujące znaczącą ważność religii w życiu w 59,3\% uczestniczyły regularnie we mszy św. niedzielnej, osoby, dla których religia jest czymś nieważnym - w $9,1 \%{ }^{52}$.

Zebrane wyniki empiryczne w Puławach świadczą, że przynajmniej dla dwóch piątych respondentów nakaz uczestniczenia we mszy św. niedzielnej stracił moc obowiązującą, z kategorycznego nakazu przekształcił się w nakaz fakultatywny albo nic nie znaczący postulat (odchodzenie od kultury obowiązku do kultury wyboru). Praktykujący regularnie maturzyści puławscy są już w mniejszości. Według dorywczych obserwacji duszpasterzy i obliczeń frekwencji w kościołach uczestnictwo w praktykach niedzielnych od początku XXI wieku wyraźnie zmniejsza się. Tę zmniejszającą się frekwencję odnotowują już ankiety socjologów. Trend spadkowy praktyk religijnych maturzystów puławskich jest faktem społecznym.

Dokonujący się obecnie powolny proces spadku praktyk religijnych w społeczeństwie polskim skłania do postawienia pytań o przyszłe kształty społeczne Kościoła katolickiego i jego miejsce w pluralistycznym społeczeństwie. Regres praktyk religijnych jest dobrym predykatorem zmian w religijności polskiej. Wydaje się, że w ostatnich kilku latach zwiększa się kategoria praktykujących rzadko lub (prawie)niepraktykujących („bywanie w kościele”, ,praktyki przy okazji”, ,praktyki od przypadku do przypadku”). Dalszy wzrost wskaźników osób praktykujących okazjonalnie lub w ogóle niepraktykujących może pociągnąc za sobą konsekwencje w innych wymiarach religijności, np. w parametrze wiary religijnej.

\section{UWAGI KOŃCOWE}

Według Anny Przecławskiej: „Młodzież generalnie deklaruje swoją przynależność do religii katolickiej, ale jej poglądy są bardzo niespójne, a stosunek do religii wybiórczy. Deklaracja przynależności do Kościoła Katolickiego wcale nie oznacza uczestniczenia w praktykach religijnych i zgodności poglądów etycznych

${ }^{52}$ Ewa Miszczak. Świętość w religijnej świadomości maturzystów województwa lubelskiego. Studium socjologiczne. Wydawnictwo UMCS. Lublin 2014 s. 127-131 i 356. 
z zadami głoszonymi przez Kościół. Wskazują na to wyniki niemal wszystkich współczesnych badań dotyczących polskiej młodzieży" "53. Tę uogólnioną konstatację dotyczącą młodzieży polskiej potwierdzają wyniki badań socjologicznych zrealizowanych w latach 1994-2016 w środowiskach maturzystów puławskich. Na podstawie zebranego materiału empirycznego trudno jest przewidywać dalszy rozwój religijności młodzieży. Diagnoza nie oznacza prognozy, przyszłość jest do pewnego stopnia niewiadomą. Tym bardziej na podstawie obrazu dzisiejszej młodzieży tylko częściowo można sobie wyobrażać kondycję religijną przyszłego społeczeństwa. Na podstawie zebranego materiału empirycznego możemy sformułować kilka ogólnych wniosków:

a) Maturzyści puławscy wyraźnie rzadziej niż dorośli Polacy deklarują się jako katolicy (różnica około 10\%). W latach 1994-2016 nastąpił najpierw na początku XXI wieku wzrost odsetka przyznających się do katolicyzmu, a potem spadek od poziomu 82,2\% (o 1,7\% mniej niż w 1994 roku). Podobnie ewoluował pogląd, że dobry Polak to katolik. Po wzroście aprobaty tego poglądu w latach 1994-2009, nastąpił jego spadek o 7,4\% w 2016 roku.

b) Przeprowadzone badania socjologiczne wśród maturzystów puławskich wskazały na stały spadek przynależności religijnej (głęboko wierzący lub wierzący), nieco spowolniony w latach 2009-2016. Aktualnie 61,8\% badanych maturzystów określiło siebie jako wierzących, około co szósty jako niezdecydowany w sprawach wiary, co dziesiąty jako obojętny religijnie i co dziesiąty jako niewierzący. Maturzyści puławscy prezentują niższy poziom przynależności religijnej niż ogół młodzieży polskiej (badania CBOS) i znacznie niższy niż ogół dorosłych Polaków (różnica około $30 \%$ ).

c) W warunkach modernizującego się społeczeństwa polskiego zmniejsza się zaangażowanie Polaków w praktyki religijne, chociaż niekoniecznie według schematów zachodnioeuropejskiej dechrystianizacji. W środowiskach młodzieżowych spadek regularnych praktyk niedzielnych jest szczególnie widoczny. Wśród maturzystów puławskich zaznaczył się spadek regularnych praktyk niedzielnych od 45,1\% w 1994 roku, do 24,4\% w 2016 roku (różnica 20,7\%). Prawie połowa badanych maturzystów praktykuje kilka razy w roku, lub w ogóle nie uczestniczy w niedzielnej mszy św. (46,2\%). Emigracja młodzieży z Kościoła jest bardziej wyraźna na poziomie praktyk niedzielnych niż deklarowanej wiary religijnej. Erozja kościelności następuje szybciej niż erozja religijności.

d) Cechy demograficzne i społeczne różnicują w wyraźny sposób deklarowane postawy wobec religii i zachowania (praktyki) religijne. Kobiety częściej niż mężczyźni deklarują przynależność wyznaniową i religijną, pogląd o nierozerwalnym związku katolicyzmu i polskości, częściej uczestniczą w regularnych praktykach

${ }^{53}$ Anna Przecławska. Współczesna młodzież polska - jaka jest? Próba poszukiwania odpowiedzi. W: W trosce o młodzież. Edukacja, praca, obywatelstwo. Red. Jan Niewęgłowski. Wydawnictwo Salezjańskie. Warszawa 2004 s. 31. 
religijnych. Młodzież z liceów ogólnokształcących rzadziej niż młodzież z techników uznaje nierozłączność polskości i katolicyzmu, częściej uczęszcza do kościoła w niedzielę, rzadziej uznaje się za osoby głęboko wierzące lub wierzące. Młodzież mieszkająca na wsi lub w małych miastach częściej niż mieszkająca w Puławach deklaruje postawy i zachowania proreligijne. Procesy sekularyzacyjne zaznaczają się wyraźniej wśród mężczyzn, młodzieży z liceów ogólnokształcących oraz mieszkającej na wsi lub w małych miastach.

Jeżeli nawet w latach 1994-2016 nie mieliśmy do czynienia z gwałtowanym przyspieszeniem procesów sekularyzacyjnych w środowiskach młodzieżowych, to jednak spadające wskaźniki deklaracji proreligijnych i praktyk kultowych w kolejnych okresach badań socjologicznych można traktować jako oznaki trendu sekularyzacyjnego. W każdym razie nie ma oznak ożywienia religijnego ani radykalnej sekularyzacji. „Pełzająca” sekularyzacja w środowiskach młodzieżowych, wyraźnie przyspieszająca, wydaje się faktem społecznym.

\section{BIBLIOGRAFIA}

Babiński Grzegorz. Religia i tożsamość narodowa - zmieniające się relacje. W: Religia i kultura w globalizującym się świece. Red. Marian Kempny, Grażyna Woroniecka. Zakład Wydawniczy NOMOS. Kraków 1999 s. 197-211.

Boguszewski Rafał. Oceny zmian w różnych wymiarach życia społecznego i politycznego w Polsce po roku 1989. „Komunikat z badań CBOS” 2014 nr 62.

Boguszewski Rafał. Od zinstytucjonalizowanej do zindywidualizowanej: religijność Polaków w procesie przemian. W: Globalny i lokalny wymiar religii. Polska w kontekście europejskim. Red. Irena Borowik, Andrzej Górny, Wojciech Świątkiewicz. Zakład Wydawniczy NOMOS. Kraków 2016 s. 135-147.

Boguszewski Rafał. Zmiany podstawowych wskaźników religijności po śmierci Jana Pawła II. W: Religijność i Kościół 10 lat po śmierci Jana Pawła II. Red. Mirosława Grabowska. CBOS. Warszawa 2015 s. 35-48.

Borowik Irena. Przemiany religijne w Polsce na tle transformacji w Europie Środkowo-Wschodniej i globalizacji. W: Globalny i lokalny wymiar religii. Polska w kontekście europejskim. Red. Irena Borowik, Andrzej Górny, Wojciech Świątkiewicz. Zakład Wydawniczy NOMOS. Kraków 2016 s. 7-16.

Borowik Irena. Religijność w Polsce okresu transformacji - na tropach zmian. W: Polska początku XXI wieku: przemiany kulturowe i cywilizacyjne. Red. Krzysztof Frysztacki, Piotr Sztompka. Komitet Socjologii PAN. Warszawa 2012 s. 331-348.

Ciecieląg Paweł, Boryszewski Paweł. Zaangażowanie religijne. W: Jakość życia w Polsce 2015 r. Wynik badania spójności społecznej. GUS. Warszawa 2017 s. 113-142.

Dardziński Piotr. Religijny potencjał młodego pokolenia. W: Portret młodego pokolenia. Red. Michał Łuczewski. Instytut Badań nad Gospodarką Rynkową. Gdańsk 2009 s. 33-36.

Floris Franco. Modlitwa (wychowanie do modlitwy). W: Słownik katechetyczny. Tł. Krystyna Kozak. Wydawnictwo Salezjańskie. Warszawa 2007 s. 606-611.

Gennerich Carsten, Feige Andreas. Jugend und Religion in neuer Perspektive: Empirisch valide Forschungsergebnisse durch eine theoretisch angemessene Fundierung. ,International Journal of Practical Theology" 2009 nr 3 s. 22-45. 
Giddens Anthony [współpraca Philip W. Sutton]. Socjologia. Tł. Olga Sara, Alina Szulżycka, Paweł Tomanek. Wydawnictwo Naukowe PWN. Warszawa 2012.

Głowacki Antoni. Patriotyzm, nacjonalizm i stosunek do obcych. W: Młodzież 2016. Raport z badania sfinansowanego przez Krajowe Biuro ds. Przeciwdziałania Narkomanii. CBOS. Warszawa 2016 s. 114-129.

Głowacki Antoni. Religijność młodzieży. W: Młodzież 2016. Raport z badania sfinansowanego przez Krajowe Biuro ds. Przeciwdziałania Narkomanii. CBOS. Warszawa 2016 s. 130-140.

Jasińska-Kania Aleksandra. Dynamika zmian wartości Polaków na tle europejskim: EVS 1990 - 1999 -2008. W: Polska po 20 latach wolności. Red. Marta Bucholc, Sławomir Mandes, Tadeusz Szawiel, Joanna Wawrzyniak. Wydawnictwa Uniwersytetu Warszawskiego. Warszawa 2011 s. 225-239.

Kanios Anna. Społeczne kompetencje studentów do pracy w wolontariacie. Wydawnictwo Uniwersytetu Marii Curie-Skłodowskiej. Lublin 2010.

Konferencji Episkopatu Polski. Chrześcijański kształt patriotyzmu. Wydawnictwo Diecezji Tarnowskiej Biblos. Tarnów 2017.

Koseła Krzysztof. Religijność młodych Niemców i Polaków. W: Młodzi Polacy i młodzi Niemcy w nowej Europie. Red. Krzysztof Koseła, Bernardette Jonda. Wydawnictwo Instytutu Filozofii i Socjologii PAN. Warszawa 2005 s. 249-283.

Koseła Krzysztof. Zmiany religijności młodzieży zarejestrowane w danych w Centrum Badania Opinii Społecznej. W: Dzieci swojego czasu. Młodzież polska i francuska. Ośrodek Badań Młodzieży Uniwersytetu Warszawskiego. Red. Joanna Kośmider, Anna Tyszkiewicz. Warszawa 1993 s. 92-97.

Lissowski Grzegorz. Metody ilościowe. W: Encyklopedia socjologii. T. 2. Red. Władysław Kwaśniewicz. Oficyna Naukowa. Warszawa 1999 s. 217-227.

Maj-Gadomska Beata. Wartości moralne w świadomości maturzystów (na podstawie badań socjologicznych w Puławach). Lublin 1995 (mps pracy magisterskiej).

Mariański Janusz. Patriotyzm i religia jako wartości podstawowe w świadomości polskich maturzystów. „Studia Płockie” 25: 1997 s. 175-192.

Miszczak Ewa. Świętość w religijnej świadomości maturzystów województwa lubelskiego. Studium socjologiczne. Wydawnictwo UMCS. Lublin 2014.

Nastalska Dorota. Wartości moralne w świadomości maturzystów. Na przykładzie wybranych szkół Puław. Lublin 2010 (mps pracy magisterskiej).

Panecka Ewa. Środowiskowe uwarunkowania zachowań altruistycznych młodzieży licealnej. Lublin 2015 (mps pracy doktorskiej).

Pickel Gert. Religionssoziologie. Eine Einführung in die zentrale Themenbereiche. VS Verlag für Sozialwissenschaften. Springer Fachmedien. Wiesbaden 2011.

Podstawka Krzysztof. Młodzież Lubelszczyzny wobec wartości moralnych. W: Edukacja w perspektywie oczekiwań współczesności. Red. Anna Karpińska, Katarzyna Borawska-Kalbarczyk, Alina Szwarc. Wydawnictwo Adam Marszałek. Toruń 2016 s. 299-323.

Przecławska Anna. Współczesna młodzież polska - jaka jest? Próba poszukiwania odpowiedzi. W: W trosce o młodzież. Edukacja, praca, obywatelstwo. Red. Jan Niewęgłowski. Wydawnictwo Salezjańskie. Warszawa 2004 s. 25-37.

Rocznik Statystyczny Rzeczypospolitej Polskiej. GUS. Warszawa 2015.

Rola Marcin. Wartości moralne w świadomości maturzystów lubelskich. Studium socjologiczne. Wydawca i druk Drukarnia Standruk. Lublin 2016.

Spiegel Egon. Współczesne problemy i perspektywy pedagogiki religii. W: Barwy nauki. Nowoczesne technologie ICT w upowszechnianiu osiągnięć nauki. Red. Sławomir Nowosad, Bożena Żurek. Katolicki Uniwersytet Lubelski Jana Pawła II. Towarzystwo Naukowe KUL. Lublin 2010 s. 427-471. 
Szymańczak Jolanta. Pogodzeni z losem, czyli o młodzieży okresu przemian. W: Dawne i nowe problemy społeczne. Szkice do obrazu społeczeństwa polskiego u progu XXI stulecia. Red. Andrzej Kojder. Kancelaria Sejmu. Warszawa 2002 s. 110-130.

Szymczyk Jan. Przemiany wartości Polaków. Wybrane aspekty i tendencje. W: Społeczne i etyczne aspekty rozwoju społecznego. Red. Witold Jedynak, Jarosław Kinal. Wydawnictwo Uniwersytetu Rzeszowskiego. Rzeszów 2015 s. 17-22.

Święs Kazimierz. Obraz współczesnej młodzieży w Polsce. „Warszawskie Studia Pastoralne UKSW" 9: 2014 nr 2 s. 33-54.

Teraźniejszość i przyszłość religii w Europie Zachodniej. „Chrześcijanin w Świecie” 17: 1985 nr 6 s. 24-36.

W czym oddaliliśmy się od Ewangelii? Koniec drugiego tysiącleci wymaga rachunku sumienia. „L' Osservatore Romano” 15: 1994 nr 1 s. 23-26.

Wnuk-Lipiński Edmund. Świat międzyepoki. Globalizacja, demokracja, państwo narodowe. Wydawnictwo ZNAK. Instytut Studiów Politycznych PAN. Kraków 2004.

Zaręba Sławomir H. Identyfikacje religijne i dylematy moralne uczniów i studentów w Polsce. „Collectanea Theologica” 79: 2009 nr 1 s. 165-195.

Zaręba Sławomir H. W kierunku jakiej religijności? Studia nad katolicyzmem polskiej młodzieży. Zakład Wydawnictw Statystycznych. Warszawa 2008.

Ziebertz Hans-Georg. Gibt es einen Tradierungsbruch? Befunde zur Religiosität der jungen Generation. W: Bertelsmann Stiftung. Religionsmonitor 2008. Gütersloher Verlagshaus. Gütersloh 2008 s. 44-53.

\section{Streszczenie}

W niniejszym artykule omówimy tylko kilka wybranych kwestii związanych z religijnością maturzystów puławskich, badanych w trzech przekrojach czasowych $(1994,2008 / 2009,2016)$ : przynależność wyznaniowa, przynależność religijna, katolicyzm i polskość, autodeklaracje praktyk religijnych. W głównej hipotezie badawczej zakładamy, że młodzież maturalna znajduje się już w fazie zaawansowanej młodości, częściowo uniezależnia się już od rodziny pochodzenia, jej główne zainteresowania i działania przenoszą się poza rodzinę. Rozpoznaje ona już dokładnie swoje perspektywy życiowe, a równocześnie coraz wyraźniej ustala swoją hierarchię wartości i autonomię moralną. Następuje także zachwianie, a niekiedy i rozpad ukształtowanych w rodzinie wartości i norm, które w coraz mniejszym stopniu wpływają na postępowanie jednostek. Zdecydowanie większe zmiany w religijności odnoszą się do praktyk religijnych (spadek praktyk regularnych w latach 1994-2016 wynosił 20,7\%).

Słowa kluczowe: maturzyści, przynależność wyznaniowa, przynależność religijna, praktyki religijne, sekularyzacja. 


\title{
RELIGIOSITY OF THE PUŁAWY HIGH SCHOOL GRADUATES IN THE PROCESS OF SOCIAL CHANGE
}

\begin{abstract}
Su m mary
In this article, we will discuss a few selected issues related to the religiosity of Puławy high school graduates, and these are: religious affiliation, Catholicism and Polishness, and self-declarations of religious practices. The study was conducted at three intervals 1994, 2008/2009, 2016. Our main research hypothesis assume that the young people in the last year of high school are already in advanced stage of adolescence, partly becoming independent from their family of origin, and their main interests and activities move beyond the family. At that stage of their development, the young people recognize precisely their life prospects and at the same time increasingly determine their hierarchy of values and moral autonomy. The distortion, and sometimes the disintegration of family values and norms occur, and these increasingly affect the behavior of individuals. Significant changes in religiosity refer to religious practices (decline in regular practice in 1994-2016 was 20.7\%).
\end{abstract}

Keywords: High School graduates, religious affiliation, religious practices, secularization. 